\title{
Detection of Potato mop-top virus in Potato Tubers and Sprouts: Combinations of RNA2 and RNA3 Variants and Incidence of Symptomless Infections
}

\author{
Satu Latvala-Kilby, Johanna M. Aura, Neda Pupola, Asko Hannukkala, and Jari P. T. Valkonen
}

\begin{abstract}
First and fourth authors: MTT Agrifood Research Finland, Plant Production Research, FIN-31600 Jokioinen, Finland; second and fifth authors: Plant Pathology Laboratory, Department of Applied Biology, P.O. Box 27, FIN-00014 University of Helsinki, Finland; and third author: State Plant Protection Service, National Phytosanitary Laboratory, Lielvārdes street 36/38, Riga, LV-1006 Latvia.

Current address of third author: Latvia State Institute of Fruit-Growing, Graudu Street 1, Dobele, LV-3701 Latvia. Accepted for publication 2 January 2009.
\end{abstract}

\section{ABSTRACT}

Latvala-Kilby, S., Aura, J. M., Pupola, N., Hannukkala, A., and Valkonen, J. P. T. 2009. Detection of Potato mop-top virus in potato tubers and sprouts: combinations of RNA2 and RNA3 variants and incidence of symptomless infections. Phytopathology 99:519-531.

Potato mop-top virus (PMTV, genus Pomovirus) causes severe quality problems by inducing necrotic arcs (spraing symptoms) in potato tubers. In this study, coat protein (CP) gene and read-through domain of RNA2 and $8 \mathrm{~K}$ gene and $3^{\prime}$ untranslated region of RNA3 were characterized from 37 PMTV isolates detected in tubers from fields in Finland and a screenhouse in Latvia. Two distinguishable types of RNA2 and RNA3 were found, each showing only little genetic variability. Sequencing and restriction fragment length polymorphism analysis of polymerase chain reaction amplicons indicated that the majority of PMTV isolates infecting tubers comprise restrictotypes RNA2-II and RNA3-B. The incidence of PMTV-infected tubers in 2006 (2007) was 55 (60), 33 (39), and 62 (68)\% in cvs. Kardal, Saturna, and Nicola, respectively, grown in the same field in 2006 (2007). Incidence of PMTV-infected tubers that were symptomless was $100(90) \%$ in Kardal and $88(44) \%$ in Saturna, and also high in cvs. Bintje (95\%) and Van Gogh (63\%), tested only in 2006, whereas it was only 12 (2)\% in Nicola. Hence, reliance on visual inspection of spraing will miss a large proportion of infected tubers and risk spreading PMTV to new fields in seed tubers. No specific combination of the types of RNA2 and RNA3 was associated with spraing-expressing or symptomless tubers. Using recombinant PMTV CP for comparison, the concentrations of PMTV CP in tuber and sprout tissue were estimated to reach $57 \mu \mathrm{g} / \mathrm{g}$. Sprout sap interfered less with enzyme-linked immunosorbent assay than did tuber sap.
Potato mop-top virus (PMTV) is the type member of the genus Pomovirus (47). It is transmitted by the protoctist Spongospora subterranea (Wallr.) Lagerh., the causal agent of powdery scab on potato $(10,15)$. PMTV was first detected in Northern Ireland, England, and Scotland (4). PMTV occurs also in South America $(25,38,45)$, Japan (14), Canada, and the Unites States (51). It was once reported in The Netherlands (48) but no further reports of its occurrence there or in other countries of central Europe are available, except Czech Republic, where it has been found $(5,30)$. In Scandinavia, PMTV was detected in Norway in the 1960s (3) but gained attention in other Nordic countries only in the 1980s and was found in Sweden (36), Finland (21), and Denmark (28). The spraing symptoms caused by PMTV typically include brown arcs or rings in tuber flesh (40) and are sometimes visible on the tuber surface (21). The symptoms were probably initially confused with those caused by Tobacco rattle virus (TRV) $(4,28)$ that occurs in potato also in southern parts of Scandinavia $(28,39)$. Today, the spraing disease caused by PMTV is one of the most important quality problems in potato production in the Nordic countries. PMTV is difficult to control because the virus remains infective in the resting spores of $S$. subterranea in soil for a long time (15) and because PMTV-resistant cultivars are not available $(28,39,40)$. In contrast to the wide distribution of PMTV in

Corresponding author: J. Valkonen; E-mail address: jari.valkonen@helsinki.fi

* The $\boldsymbol{e}$-Xtra logo stands for "electronic extra" and indicates that the online version contains a figure showing alignments of the PMTV sequences analyzed.

doi:10.1094/PHYTO-99-5-0519

(C) 2009 The American Phytopathological Society
Scandinavia, PMTV has not been reported to occur in other countries of the Baltic Sea region. An international research program carried out by the Nordic and Baltic countries, Germany, Poland, and Russia since 2005 has defined the current geographic distribution of PMTV in the Baltic Sea region, which is now used to plan measures by which further spread of the virus could be restricted.

PMTV has a three-partite, single-stranded RNA genome (16). The size of RNA1 in the Swedish isolate PMTV-Sw is 6,043 nucleotides (nt). It encodes the viral RNA-dependent RNA polymerase (RdRp) (43). RNA2 (3,134 nt in PMTV-Sw) contains an open reading frame (ORF) $(531 \mathrm{nt})$ for the $20-\mathrm{kDa}$ coat protein (CP). It also produces a larger protein ( $91 \mathrm{kDa}$ in PMTV-Sw) by readthrough (RT) of the amber termination codon of the $\mathrm{CP}$ $(17,41)$. The RT domain is presumed to be involved in transmission of PMTV by the vector (34). The RT domain undergoes changes and shows size variability as a consequence of virus propagation in test plants by mechanical inoculation $(41,46)$. RNA3 (2,964 nt in PMTV-Sw) contains a triple-gene block (TGB) that encodes three proteins involved in cell-to-cell movement $(44,52)$. The fourth ORF of RNA3 encodes an 8-kDa cystein-rich protein with an unknown function (44). The $8 \mathrm{~K}$ protein induces necrotic symptoms in plants when expressed from heterologous viruses (24). RNA2 and the $8 \mathrm{~K}$ gene of RNA3 are dispensable for systemic movement of PMTV in Nicotiana benthamiana plants (42).

In many parts of Scandinavia, little is known about the genetic variability of PMTV. All in all, partial sequences of only nine isolates from Denmark, Sweden, Czech Republic, Scotland, and Canada and the complete sequence of one Swedish isolate are available from public databases $(5,17,24,31,34,41,43,44,51)$. Some 
studies have not deposited their sequence data to databases (25, 29). Therefore, this study aimed to characterize the genetic variability of PMTV in Finland and Latvia, which has not been reported, and substantially increase the sequence data available for comparison in future studies. Tubers infected with PMTV may not always show symptoms $(22,39,40)$ but it is not known whether symptoms or symptomless infections are associated with particular strains or variants of PMTV. Therefore, the aim of this study was to survey the genetic variability of PMTV based on the $\mathrm{CP}$ and RT sequences of RNA2 and the $8 \mathrm{~K}$ gene and 3 ' untranslated region (3'UTR) sequences of RNA3 and correlate occurrence of the possible genetic variants of the virus with symptoms observed in tubers of different cultivars. Differences in the incidence of symptomless infections between cultivars were tested. To further facilitate detection of symptomless infections in tubers, the feasibility of detecting PMTV in sprouts was compared with tuber tissue that is normally used for testing this virus.

\section{MATERIALS AND METHODS}

Plant material. Tubers of commonly grown cultivars such as Annabelle, Cecile, Lady Claire, Nicola, Saturna, Seresta, Tanu, Timo, Van Gogh, and Velox with typical spraing symptoms (Fig. 1) were collected from the main potato production areas at the western coast and Åland Islands (Ahvenanmaa) of Finland in 2005 and 2006 (Fig. 2). Furthermore, minitubers of Saturna grown from in vitro plantlets in a screenhouse of a commercial enterprise in Latvia in 2005 were subjected to indexing for PMTV.

Pathogen-indexed minitubers and seed potato for use as negative controls in virus tests or for planting in field trials were obtained from seed potato companies (Finnish Seed Potato Center and Northern Seed Potato, both located in Tyrnävä, Finland). Minitubers of Annabelle were grown from pathogen-free in vitro plantlets in a growth chamber at University of Helsinki.

$N$. benthamiana plants were grown from seed in a growth chamber under constant conditions (photoperiod, $16 \mathrm{~h}$; light intensity, $100 \mathrm{Em}^{-2} \mathrm{~s}^{-1}$; temperature, 20 and $18^{\circ} \mathrm{C}$, day and night, respectively; and relative humidity, $45 \%$ ) and watered when needed with $0.05 \%$ solution of $\mathrm{N}: \mathrm{P}: \mathrm{K}=16: 9: 22$ fertilizer.

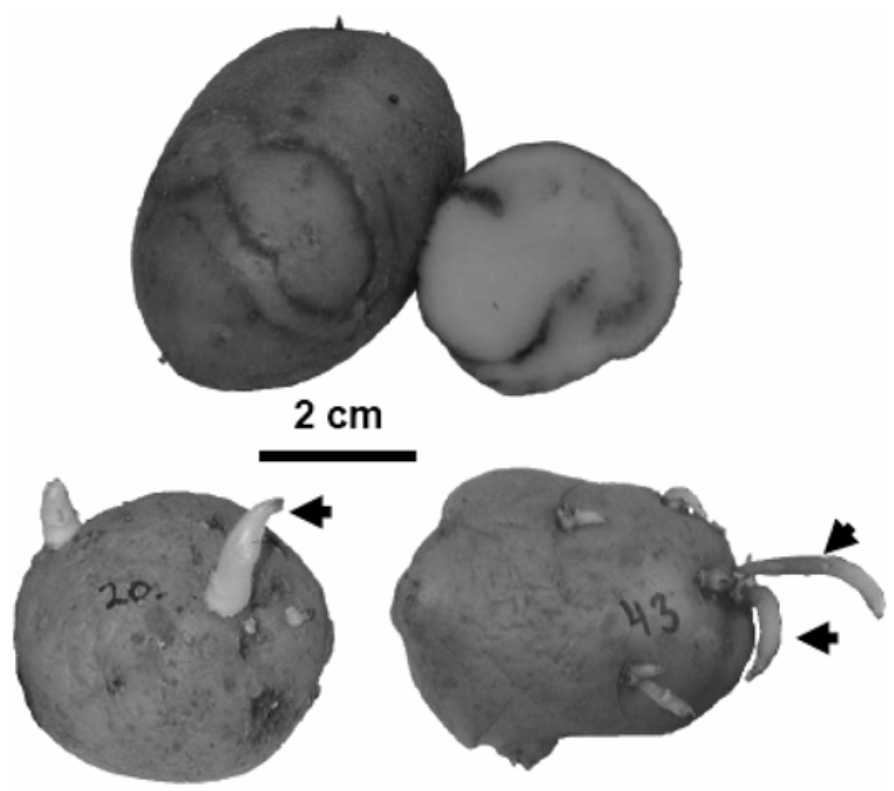

Fig. 1. Typical spraing symptoms caused by Potato mop-top virus (PMTV) in potato tubers (cv. Nicola, on the top). Tissue samples were excised from the surface of the tuber from places where symptoms were observed and tested for PMTV. Sprouted tubers below show the size of the sprouts tested for PMTV (sprouts indicated by arrowheads were sampled).
Incidence of symptomless PMTV-infected tubers. Cultivars Bintje, Kardal, Nicola, Saturna, and Van Gogh were grown from pathogen-indexed seed potato in a potato cultivar testing field with 25 additional cultivars. The experiment was established in a farmer's field heavily infested with PMTV in Harjavalta, SouthWestern Finland $\left(61.279164^{\circ} \mathrm{N}, 22.203833^{\circ} \mathrm{E}\right)$. The trial was arranged according to complete randomized block design with three replicates. Each plot consisted of 28 pathogen-indexed seed tubers planted per row $(8.5 \mathrm{~m})$. Potato tubers were planted on 25 May in both years (2006 and 2007) and harvested after 110 and 108 days, respectively. Rainfall in the growing period was 199 and $223 \mathrm{~mm}$ in 2006 and 2007, respectively. The mean temperatures (minimum and maximum) were 9.95 and 21.1 in 2006 and 9.92 and $19.8^{\circ} \mathrm{C}$ in 2007 . Fertilization $(80 \mathrm{~kg} \mathrm{~N} / \mathrm{ha}$ ), control of late blight (five sprays with mancozeb or fluazinam during the growing season), weed control, and other cropmanagement practises were carried out by the farmer according to the specified recommendations for starch potato production (Loris Expert analysis program; Kemira GrowHow, Espoo, Finland).

Visual inspection of spraing symptoms and statistical analysis of the proportions of symptomless tubers. After harvest, the tubers were stored in darkness. They were first kept at $20^{\circ} \mathrm{C}$ for a week and then at $8^{\circ} \mathrm{C}$ for 7 weeks, after which all tubers were split in half through the middle. The tubers with spraing symptoms were counted and separated from the rest. Symptomless tubers were stored further in darkness at $20^{\circ} \mathrm{C}$ for a week and then at $8^{\circ} \mathrm{C}$ for 2 to 3 weeks. The second scoring of symptoms was done by splitting the tubers into small pieces to reveal even the smallest necrotic arcs in tuber flesh.

The total number of tubers inspected for symptoms and the number of symptomless tubers tested for PMTV (in parentheses)

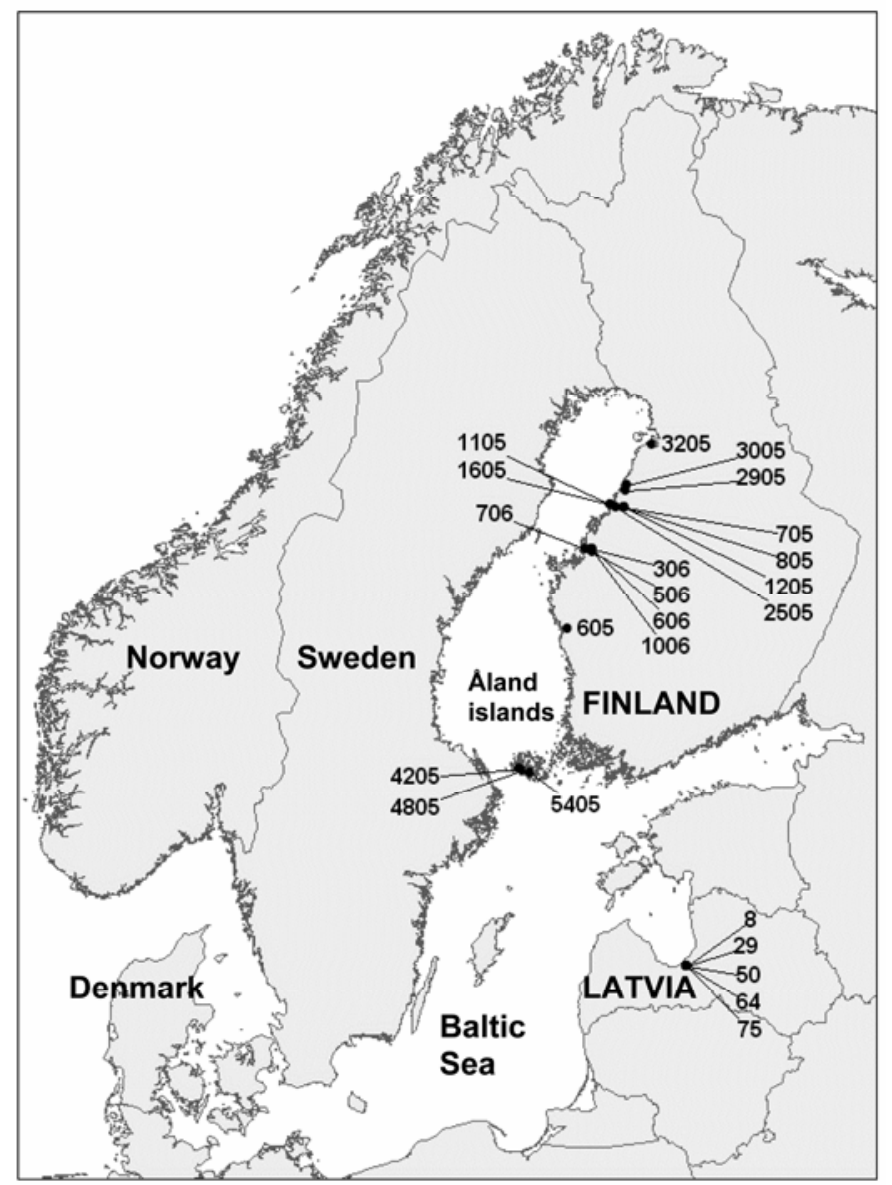

Fig. 2. Sampling sites of the Potato mop-top virus isolates subjected to sequence analysis. 
in 2006 were 511 (54) in Bintje, 342 (162) in Kardal, 489 (162) in Nicola, 486 (162) in Saturna, and 483 (54) in Van Gogh. In 2007, 449, 450, and 422 tubers of Kardal, Nicola, and Saturna were inspected for symptoms and 162 symptomless tubers of each cultivar were tested for PMTV.

Differences in the proportions of symptomatic or symptomless tubers and the proportions of symptomless PMTV-infected tubers between cultivars was done with the proportional odds model (logit version of an ordinal regression model) (32). Year and experimental block were included in the model as explanatory variables. These analyses were performed by the SAS/LOGISTIC procedure (1) in SAS/STAT (version 9; SAS Institute Inc., Cary, NC). Cvs. Nicola, Saturna, and Kardal were analyzed separately from Bintje and Van Gogh, which were included in the study only in 2006.

Sample preparation from tubers. Samples for doubleantibody sandwich enzyme-linked immunosorbent assay (DASELISA) and immunocapture reverse-transcription polymerase chain reaction (IC-RT-PCR; see below)-based detection of PMTV were prepared from washed tubers using one of the following methods. Tissue $\left(1 \mathrm{~cm}^{2}\right.$ at a depth of $\left.5 \mathrm{~mm}\right)$ was excised with a knife from the tuber surface from places where the spraing symptoms were visible. When no symptoms were visible, a 5-mm thick slice was cut from the stolon end of the tuber. The sampled tissue was frozen in liquid nitrogen and defrosted; then, sap was pressed out from the tissue into an Eppendorf tube using a sap-pressing equipment (Pollähne leaf press; Elektrowerk Hannover, Behncke \& Co., Hannover, Germany). Alternatively, the sample was not frozen but processed fresh in polyvinyl bags $(\approx 15 \mathrm{~cm}$ high and $10 \mathrm{~cm}$ wide) according to the method that has been introduced by R. A. C. Jones when working at the International Potato Center (CIP), Peru. Tuber tissue $(\approx 0.5 \mathrm{~g})$ was placed in the bag, $2 \mathrm{ml}$ of ELISA extraction buffer (500 mM Tris- $\mathrm{HCl}$ [pH 7.4], $2 \%$ polyvinyl pyrrolidone [PVP-40], 1\% polyethylene glycol [PEG 8000], $140 \mathrm{mM} \mathrm{NaCl}$, and $0.05 \%$ Tween 20) (35) was added, and the tissue was crushed with a hammer.

Sample preparation from sprouts. For testing sprouts, the tubers of Annabelle, Seresta, Tanu, Timo, and Velox were indexed for PMTV by DAS-ELISA. The PMTV-positive tubers were stored at $4{ }^{\circ} \mathrm{C}$ until the dormancy broke naturally (after 4 to 6 months) and they contained sprouts longer than $2 \mathrm{~cm}$. Tubers were moved from 4 to $18^{\circ} \mathrm{C}$ and kept in dark for 10 days prior to testing the sprouts for PMTV. Up to five sprouts $>2 \mathrm{~cm}$ in length (Fig. 1) were sampled from five PMTV-infected tubers per cultivar. A sample was also taken from the stolon end of the tuber, as above. Sprout and tuber samples were processed using the polyvinyl bag methods and tested for PMTV by DAS-ELISA as described below. Sprouts from three to five tubers were tested in two experiments. To estimate the detection threshold, the sap of PMTV-infected sprouts was diluted at the ratio of 1 to $2,10,20$, $30,40,50$, and 100 with the sap from virus-free sprouts and tested for PMTV by DAS-ELISA.

Mechanical inoculation of $N$. benthamiana. Mechanical inoculation of PMTV from sprouts to $N$. benthamiana was done by weighing the sprout, grinding it in a mortar with a pestle, and diluting the sap with water $1: 2(\mathrm{wt} / \mathrm{vol})$. The sap was rubbed on two Carborundum-dusted lower leaves of 7-week-old N. benthamiana plants. Plants were grown under the conditions specified above. Leaves and roots were tested for PMTV 18 days postinoculation (dpi). The tissue was ground in a polyvinyl bag at $1 \mathrm{~g}$ per $3 \mathrm{ml}$ of ELISA extraction buffer. DAS-ELISA was carried out as above. Leaves and roots of healthy and PMTV-infected $N$. benthamiana were included as controls.

Detection of PMTV by DAS-ELISA. Monoclonal antibodies $(\mathrm{MAb})$ and alkaline phosphatase (AP)-conjugated MAbs to PMTV were obtained from Scottish Agricultural Science Agency (SASA, Ayr, Scotland) or the same antibodies were purchased via Bioreba (Reinach, Switzerland). Microtiter plates (Greiner Labor- teknik, Frickenhausen, Germany) were coated with the antiPMTV MAb diluted 1:1000 with coating buffer (15 $\mathrm{mM} \mathrm{Na}_{2} \mathrm{CO}_{3}$, $34.5 \mathrm{mM} \mathrm{NaHCO}_{3}, \mathrm{pH}$ 9.6). Two aliquots $(100 \mu \mathrm{l})$ of the tissue homogenate were transferred to two wells of a microtiter plate precoated with PMTV MAb. The plate was incubated at $4^{\circ} \mathrm{C}$ overnight. Next morning the plate was emptied and washed $3 \times$ 3 min with phosphate-buffered saline with Tween (PBS-T) buffer, consisting of PBS $\left(137 \mathrm{mM} \mathrm{NaCl}, 1.5 \mathrm{mM} \mathrm{KH}_{2} \mathrm{PO}_{4}, 8 \mathrm{mM}\right.$ $\mathrm{Na}_{2} \mathrm{HPO}_{4} \times 12 \mathrm{H}_{2} \mathrm{O}$, and $2.7 \mathrm{mM} \mathrm{KCl}[\mathrm{pH} \mathrm{7.4])}$ and $0.005 \%$ Tween 20. The AP-conjugated anti-PMTV MAb was diluted 1:1,000 with PBS and $100 \mu \mathrm{l}$ added to each well. The plate was incubated at $37^{\circ} \mathrm{C}$ for $2 \mathrm{~h}$ and washed $3 \times 3$ min with PBS-T. Color reaction was developed using $p$-nitrophenyl phosphate as substrate $(0.25 \mathrm{mg}$ per $1 \mathrm{ml}$ of $9.7 \%$ diethanolamine, $\mathrm{pH} 9.8$ ). Absorbances were recorded at $405 \mathrm{~nm}\left(\mathrm{~A}_{405}\right)$ using a microtiter plate reader $4 \mathrm{~h}$ after adding the substrate.

Five lots of 100 minitubers of cv. Saturna were tested for PMTV by DAS-ELISA in Latvia as above, with a few modifications. The extraction buffer was PBS-T that contained $15 \mathrm{mM}$ $\mathrm{NaSO}_{3}$ and $0.2 \%$ ovalalbumin but no PEG. The AP-conjugated antibodies were diluted with PBS-T containing $0.2 \%$ bovine serum albumin (BSA). The substrate buffer contained $9.1 \%$ diethanolamine, $2.0 \%$ diethanolamine- $\mathrm{HCl}$, and $1.0 \mathrm{mM} \mathrm{MgCl}_{2}$.

The tubers and sprouts generating $\mathrm{A}_{405}$ values threefold higher than the mean of the negative controls (samples from virus-free tubers) were considered to be PMTV infected.

Production of recombinant CP of PMTV. The PMTV CP gene of the isolate PMTV-Sw (42) was amplified from the cDNA clone of RNA2 (AJ243719) by PCR using the forward primer 5'TATATAGGATCCATGGCTGAAAACAGAGGTG-3' (position 314-332; an added BamHI restriction site underlined) and the reverse primer 5'-TATAGTCGACCTATGCACCAGCCCAGCGT3' (position 826-845; an added SalI restriction site underlined) and Dynazyme II DNA polymerase (Finnzymes, Espoo, Finland). The amplified CP gene was ligated into the pQE-30 vector (The QIAexpressionist; Qiagen, Hilden, Germany) according to the manufacturer's instructions to express the CP with an N-terminal $6 x$ His-tag. The construct was verified by sequencing and transformed to Escherichia coli M15 cells for expression. Bacteria were grown in $5 \mathrm{ml}$ of Luria-Bertani (LB) medium under appropriate selection overnight. The culture was added to $50 \mathrm{ml}$ of LB and grown to an optical density at $600 \mathrm{~nm}$ of 0.5 . CP expression was induced by adding isopropyl-beta-D-thiogalactopyranoside (IPTG) (Promega Corp., Madison, WI) to the final concentration of $1 \mathrm{mM}$ and incubating the culture for $5 \mathrm{~h}$ at $28^{\circ} \mathrm{C}$ with shaking. The 6x-His-tagged $\mathrm{CP}$ was purified under denaturing conditions as described (protocols 10 and 17, The QIAexpressionist handbook, 5th edition; Qiagen). The amount of purified protein was determined using spectrophotometer and by sodium dodecyl sulfate polyacrylamide gel electrophoresis (SDS-PAGE) analysis using known amounts of BSA for comparison. The gel was dyed with PageBlue Protein Staining Solution (Fermentas, Vilnus, Litthuania) according to the manufacturer's instructions.

For producing higher amounts of 6xHis-tagged PMTV CP for use as a positive control in DAS-ELISA, the same procedure as above was followed except that IPTG was added in a higher final concentration of $2 \mathrm{mM}$ and the bacteria were grown overnight at a lower temperature of $20^{\circ} \mathrm{C}$. Bacteria were pelleted by centrifugation in 1.5-ml microtubes (Sarstedt, Nümbrecht, Germany) ( $1 \mathrm{ml}$ of culture per tube). The pellet was ground under liquid nitrogen, $500 \mu \mathrm{l}$ of ELISA extraction buffer was added, and the lysate was spun at $13,000 \times g$ for $15 \mathrm{~min}$. The supernatant was collected and the concentration of CP estimated by western blot analysis as described below.

Western blot analysis. Different concentrations of purified 6xHis-tagged PMTV CP, supernatants of the lysates of noninduced bacterial cells and cells expressing the 6xHis-tagged $\mathrm{CP}$ at $20^{\circ} \mathrm{C}$, and leaf extracts of healthy and PMTV-infected N. ben- 
thamiana plants were mixed 1:1 (vol/vol) with $2 \times$ Laemmli buffer (20\% glyserol, $100 \mathrm{mM}$ Tris- $\mathrm{HCl}$ [pH 6.8], 10\% $\beta$-mercaptoethanol, $0.2 \%$ bromophenolblue, and $4 \%$ SDS) and analyzed by SDS-PAGE. The gel was blotted to Hybond-P polyvinylidene fluoride (PVDF) membrane (GE Healthcare, Chalfont, UK) using Semi-Dry Trans-Blot Cell (BioRad, Hercules, CA) and Towbin transfer buffer (25 mM Tris, $192 \mathrm{mM}$ Glysine, and $20 \%$ methanol) (50 min at $12 \mathrm{~V}, 280 \mathrm{~mA})$. The membrane was blocked with $5 \%$ fat-free milk powder in Tris-buffered saline with Tween $(1 \times$ TBS-T) $(150 \mathrm{mM} \mathrm{NaCl}, 10 \mathrm{mM}$ Tris- $\mathrm{HCl}$, and $0.1 \%$ Tween 20 , $\mathrm{pH}$ 7.4) for $1 \mathrm{~h}$ at room temperature. Proteins were detected with an anti-His MAb (product 27471001; GE Healthcare) diluted 1:3,000 or the PMTV CP-specific MAb (SASA) diluted 1:1,000 with TBS-T containing $2.5 \%$ fat-free milk. The membrane was incubated with the MAb overnight at $4{ }^{\circ} \mathrm{C}$, washed three times for 10 min with TBS-T, and incubated with anti-mouse horseradish peroxidase-conjugated antibodies (NXA931; GE Healthcare) diluted 1:50,000 with TBS-T for $1 \mathrm{~h}$ at room temperature. The membrane was washed six times ( 5 min each) with TBS-T and once $(5 \mathrm{~min})$ with TBS. Signals were developed using SuperSignal West Femto Maximum Sensitivity Substrate (Thermo Scientific, Rockford, IL) according to the manufacturer's instructions.

Influence of sprout and tuber sap on sensitivity of serological detection of PMTV. Samples from healthy sprouts and tubers of Annabelle were prepared as above using ELISA extraction buffer that contained recombinant PMTV CP from the bacterial lysate $(800 \mathrm{ng}$ per $100 \mu \mathrm{l})$ or the ELISA extraction buffer without PMTV CP, and ELISA was carried out as before. Recombinant CP from bacterial lysates at different concentrations (800, 600, 400, or $80 \mu \mathrm{g}$ per $100 \mu \mathrm{l}$ of ELISA extraction buffer), samples from PMTV-infected tubers, and the bacterial lysate from noninduced cells with no PMTV CP were included for comparison.

Detection of PMTV by IC-RT-PCR. Immunocapture of PMTV virions was done with anti-PMTV MAb (Bioreba). An aliquot $(100 \mu \mathrm{l})$ of the antibodies diluted 1:150 with ELISA coating buffer was added to a PCR tube $(0.5 \mathrm{ml})$. The tube was incubated at $37^{\circ} \mathrm{C}$ for $2 \mathrm{~h}$ and subsequently washed twice with $100 \mu \mathrm{l}$ of PBS-T. The homogenate from a tuber was prepared using sap-pressing equipment as described above, diluted 1:1 with PBS-T, and $100 \mu \mathrm{l}$ was added to the antibody-coated PCR tube. The tube was incubated at $37^{\circ} \mathrm{C}$ for $60 \mathrm{~min}$, washed twice with $100 \mu \mathrm{l}$ of PBS-T, and finally washed once with deionized water treated with diethylpyrocarbonate (DEPC) to remove RNases.

RT-PCR was done using a single-tube approach and the lyophilized Ready-To-Go RT-PCR Beads (GE Healthcare) which contain the enzymes needed for reverse transcription and PCR. Following immunocapture of virus particles, $48 \mu$ l of DEPC- $\mathrm{H}_{2} \mathrm{O}$ and $5 \mu \mathrm{M}$ Rpr24 primer (Table 1) were added into the washed tube and the tube heated at $70^{\circ} \mathrm{C}$ for $10 \mathrm{~min}$ followed by cooling on ice for 5 min. Subsequently, $5 \mu \mathrm{M}$ Fpr25 primer (Table 1) and one Ready-To-Go RT-PCR Bead were added according to the manufacturer's instructions. RT-PCR conditions were as follows: reverse transcription at $42^{\circ} \mathrm{C}$ for $30 \mathrm{~min}$ and denaturation at $95^{\circ} \mathrm{C}$ for $5 \mathrm{~min}$, followed by 35 cycles of denaturation at $95^{\circ} \mathrm{C}$ for $30 \mathrm{~s}$, annealing at $56^{\circ} \mathrm{C}$ for $30 \mathrm{~s}$, and primer extension at $72^{\circ} \mathrm{C}$ for $30 \mathrm{~s}$. The final primer extension was done at $72^{\circ} \mathrm{C}$ for $5 \mathrm{~min}$. Amplification products were analyzed by agarose gel electrophoresis, stained with ethidium bromide, and visualized under UV-light.

Cloning fragments of the PMTV genome. Samples were prepared as above except that, before reverse transcription, $11 \mu \mathrm{l}$ of DEPC- $\mathrm{H}_{2} \mathrm{O}$ and $1 \mu \mathrm{l}$ of $20 \mu \mathrm{M} 3^{\prime}$ rev-primer (Table 1) were added to the washed sample tubes. The tubes were heated at $70^{\circ} \mathrm{C}$ for $10 \mathrm{~min}$, cooled on ice for $5 \mathrm{~min}$, and reverse transcription was carried out at $55^{\circ} \mathrm{C}$ for $45 \mathrm{~min}$ in a total reaction volume of $20 \mu \mathrm{l}$ containing $5 \mathrm{mM}$ dithiothreitol (DTT) (Invitrogen, Carslbad, CA, USA), $40 \mathrm{U}$ of RnaseOUT ribonuclease inhibitor (Invitrogen), 200 U of SuperScript III reverse transcriptase (Invitrogen), and 1× reaction buffer (Invitrogen). Reverse transcriptase was inactivated at $70^{\circ} \mathrm{C}$ for $15 \mathrm{~min}$.

Most of the RNA2 sequence was amplified as two overlapping fragments (Fig. 3). The first fragment (1,248 nt, including primer sequences) begins $23 \mathrm{nt}$ upstream from the $\mathrm{CP}$ translation start codon that is at position 314-316 of RNA2 (41). From RNA3, the $8 \mathrm{~K}$ gene and the 3'UTR were amplified (Fig. 3). The primers used for PCR amplification and the PCR conditions are listed in Table 1. The high proofreading Phusion DNA Polymerase (Finnzymes, Espoo, Finland), which shows a 25-fold higher fidelity than the Taq DNA polymerase (2), was used according to the manufacturer's instructions. PCR products were first purified using QIAquick Gel Extraction Kit (Qiagen) or QIAquick PCR Purification Kit (Qiagen) and cloned into pCR-Blunt II-TOPO vector (Invitrogen) according to the manufacturer's instructions.

Sequence analysis. DNA sequencing was carried out at the Haartmann Institute Sequencing Core Facility (University of Helsinki) using an automated DNA sequencer.

Sequences of previously characterized PMTV isolates and viruses used for comparison were obtained from sequence databases (Table 2). The sequences were analyzed using MEGA 3.1

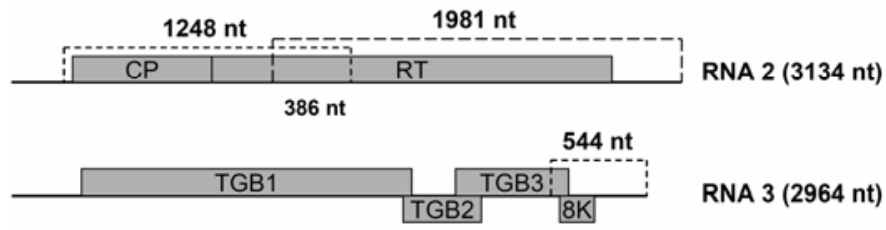

Fig. 3. Schematic presentation of the genomic structures of RNA2 and RNA3 of Potato mop-top virus (PMTV). The parts of RNA2 (overlapping fragments of 1,248 and 1,981 nucleotides [nt]) and RNA3 (544 nt) cloned and sequenced from PMTV isolates in this study are indicated by dotted lines. Open reading frames are boxed. CP, coat protein; RT, read-through domain; TGB1-3, triple gene block proteins $1-3$, respectively; $8 \mathrm{~K}$, cystein-rich protein.

TABLE 1. Primers and polymerase chain reaction (PCR) conditions used for amplification of viral sequences

\begin{tabular}{|c|c|c|c|c|}
\hline Amplified region ${ }^{\mathrm{a}}$ & Primers $^{\mathrm{b}}$ & Location $^{\mathrm{c}}$ & Primer sequence & PCR conditions \\
\hline \multirow[t]{2}{*}{ RNA2 (CP and partial RT; 1248 nt) } & F: CP1 & $292-311$ & 5'-GGTTTGTTTACCACCCTTGG-3' & $\begin{array}{l}40 \mathrm{~s} \text { at } 98^{\circ} \mathrm{C} ; 30 \text { cycles of } 10 \mathrm{~s} \text { at } 98^{\circ} \mathrm{C}, 15 \mathrm{~s} \text { at } \\
66^{\circ} \mathrm{C} \text {, and } 30 \mathrm{~s} \text { at } 72^{\circ} \mathrm{C} ; 5 \mathrm{~min} \text { at } 72^{\circ} \mathrm{C}\end{array}$ \\
\hline & R: Rpr24 & $1,518-1,539$ & 5'-TCCCTGTCACCTTCATCTATGG-3' & \\
\hline & $\mathrm{R}: 3^{\prime}$ rev & $3,114-3,134$ & 5'-TGGTCTTGGATACCCTCCAAG-3' & \\
\hline RNA3 (8K gene and 3'UTR; 544 nt) & F: 8Kfor & $2,421-2,439$ & 5'-GTAGCAAGTACGCCCTGTG-3' & $\begin{array}{l}40 \mathrm{~s} \text { at } 98^{\circ} \mathrm{C} ; 30 \text { cycles of } 10 \mathrm{~s} \text { at } 98^{\circ} \mathrm{C}, 15 \mathrm{~s} \text { at } \\
65^{\circ} \mathrm{C} \text {, and } 15 \mathrm{~s} \text { at } 72^{\circ} \mathrm{C} ; 5 \mathrm{~min} \text { at } 72^{\circ} \mathrm{C}\end{array}$ \\
\hline
\end{tabular}

\footnotetext{
${ }^{a} \mathrm{CP}$, coat protein gene; RT, read-through domain; nt, nucleotides; $3^{\prime} \mathrm{UTR}, 3^{\prime}$ untranslated region. The predicted sizes of amplification products are indicated with reference to the sequence of Potato mop-top virus (PMTV)-Sw (43).

${ }^{\mathrm{b}} \mathrm{F}$ and $\mathrm{R}=$ forward and reverse primer, respectively.

${ }^{c}$ Positions indicated with reference to the sequence of PMTV-Sw (43).
} 
software (20). ClustalW (8) was used for making sequence alignments. Phylogenetic trees were constructed using the neighborjoining (37) and maximum parsimony methods. Statistical significance was tested using 1,000 bootstrap replications.

Restrictotype analysis of PMTV strains. Restriction fragment length polymorphism (RFLP) analysis was designed for detecting the restrictotypes of PCR products of the two types of RNA2 and RNA3 that were distinguished based on differences in the CP, RT, and $8 \mathrm{~K}$ sequences. NEBcutter (49) was employed to map endonuclease restriction sites. In the 1,248-nt fragment amplified from RNA2 type I (RNA2-I), a restriction site for HinfI was identified in the CP gene and the RT domain sequence, resulting in three restriction fragments of 72,397 , and 779 nt. No Hinfl site was present in the amplification product from RNA2-II. The amplification product (544 nt) from RNA 3 type A (RNA3-A) was found to be cut with $H p a \mathrm{I}$, resulting in restriction fragments of 112 and 432 nt. No HpaI site was present in the amplification product from RNA3-B.

The aforementioned viral genome fragments were amplified by IC-RT-PCR. The products were purified using Qiaquick PCR purification kit (Qiagen) and subjected to restriction analysis with HinfI or HpaI (New England Biolabs, Ipswich, MA) at $37^{\circ} \mathrm{C}$ for $16 \mathrm{~h}$ according to the manufacturer's instructions. Restriction fragments were separated by agarose gel electrophoresis, stained with ethidium bromide, and visualized under UV light. Some PCR products which had been subjected to sequence analysis were tested using the designed restrictotype analysis to verify the method. Also, the observed restrictotype pattern from some new samples was verified by cloning and sequencing of the PCR products.

\section{RESULTS}

Detection of PMTV in tubers expressing spraing symptoms. In total, 98 tubers with spraing symptoms were collected from the field in Finland and tested for PMTV by DAS-ELISA. All tubers were PMTV-positive except four tubers that generated low $\mathrm{A}_{405}$ values at the threshold level after 1 to $2 \mathrm{~h}$ of incubation with the substrate (data not shown). However, PMTV was detected also in these four tubers by IC-RT-PCR (data not shown). Because the negative controls (virus-free minitubers or certified seed tubers) and buffer wells showed no significant increase of absorbance $\left(\mathrm{A}_{405}\right)$ values during an extended incubation time with the substrate, the plates were incubated at room temperature for $4 \mathrm{~h}\left(\mathrm{~A}_{405}\right.$ values 0.09 to 0.13 for buffer wells, 0.08 to 0.14 for negative controls, and 0.60 to 1.60 for PMTV-positive tubers) or overnight at $+4{ }^{\circ} \mathrm{C}$ to have a clear distinction between PMTV-positive and -negative samples.

Incidence of spraing symptoms and symptomless PMTV infections in tubers of different cultivars. Kardal, Nicola, and Saturna were grown in a varietal assessment field with many other cultivars in a completely randomized block design with three replicates in 2 years (2006 and 2007). The incidence of spraingexpressing tubers was $0 \%$ (number of inspected tubers, $n=489$ ) and 6\% $(n=449)$ in Kardal, $4 \%(n=486)$ and $22 \%(n=411)$ in Saturna, and 60\% $(n=489)$ and 61\% $(n=450)$ in Nicola in 2006 and 2007, respectively (Fig. 4). In both years, 162 symptomless tubers from each cultivar were tested for PMTV by IC-RT-PCR. The portions of PMTV-infected tubers among the symptomless tubers were 55 and 54\% (Kardal), 52 and 12\% (Saturna), and 8 and 1\% (Nicola) in 2006 and 2007, respectively. Because all

TABLE 2. Sequences of Potato mop-top virus

\begin{tabular}{|c|c|c|c|c|}
\hline Isolate & Accession number ${ }^{\mathrm{a}}$ & Source ${ }^{b}$ & Origin & Reference \\
\hline 306 & AM503624; AM503602 & Van Gogh & Uusikaarlepyy, Finland & This study \\
\hline 506 & AM503625; AM503603 & Van Gogh & Uusikaarlepyy, Finland & This study \\
\hline 605 & AM503611; AM503589 & Van Gogh & Kristiinankaupunki, Finland & This study \\
\hline 606 & AM503626 & Van Gogh & Uusikaarlepyy, Finland & This study \\
\hline 705 & AM503612; AM503590 & Lady Claire & Kannus, Finland & This study \\
\hline 706 & AM503627; AM503604 & Van Gogh & Uusikaarlepyy, Finland & This study \\
\hline 805 & AM503613; AM503591 & Lady Claire & Kannus, Finland & This study \\
\hline 1006 & AM503628; AM503605 & Van Gogh & Uusikaarlepyy, Finland & This study \\
\hline 1105 & AM503614; AM503596 & Nicola & Lohtaja, Finland & This study \\
\hline 1205 & AM503615; AM503592 & Lady Claire & Kannus, Finland & This study \\
\hline 1605 & AM503616; AM503593 & Nicola & Lohtaja, Finland & This study \\
\hline 2505 & AM503617; FM205706; AM503594 & Nicola & Lohtaja, Finland & This study \\
\hline 2905 & AM503618; AM503595 & Nicola & Kalajoki, Finland & This study \\
\hline 3005 & AM503619; AM503597 & Nicola & Pyhäjoki, Finland & This study \\
\hline 3205 & AM503620; AM503598 & Van Gogh & Lumijoki, Finland & This study \\
\hline 4205 & AM503621; AM503599 & Saturna & Hammarland, Finland & This study \\
\hline 4805 & AM503622; AM503600 & Saturna & Jomala, Finland & This study \\
\hline 5405 & AM503623; AM503601 & Saturna & Lemland, Finland & This study \\
\hline 8 & AM503629; AM503609 & Saturna & Riga, Latvia & This study \\
\hline 29 & AM503630; AM503607 & Saturna & Riga, Latvia & This study \\
\hline 50 & AM503631; AM503606 & Saturna & Riga, Latvia & This study \\
\hline 64 & AM503632; AM503608 & Saturna & Riga, Latvia & This study \\
\hline 75 & AM503633; AM503610 & Saturna & Riga, Latvia & This study \\
\hline $\mathrm{H} 2$ & AY327117 (CP) & Tuber nn & Canada & 51 \\
\hline Korneta & DQ102381; DQ144451 & Test plant & Czech Republic & 6 \\
\hline PMTV-D & Not in databank $(8 \mathrm{~K})$ & Soil & Denmark & 25 \\
\hline PMTV-S & AJ224991 (RT) & Soil & Scotland & 35 \\
\hline PMTV-Sw & AJ243719; AJ277556 & Soil & Sweden & 42,43 \\
\hline PMTV-T & PXMRNA3; PXMTGBP & Test plant & Scotland & 18 \\
\hline $54-10$ & AY426745 (8K) & Soil & Denmark & 32 \\
\hline $54-15$ & AY196094; AY187010 & Soil & Denmark & 32 \\
\hline $54-19$ & AF487407 (CP, RT) & Soil & Denmark & 32 \\
\hline
\end{tabular}

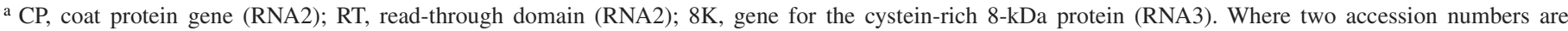
indicated, they refer to sequences of $\mathrm{CP}+\mathrm{RT}$ and $8 \mathrm{~K}$, respectively. Where three accession numbers are indicated, they refer to sequences of $\mathrm{CP}+$ partial $\mathrm{RT}$, $3^{\prime}$ proximal part of $\mathrm{RT}$, and $8 \mathrm{~K}$, respectively.

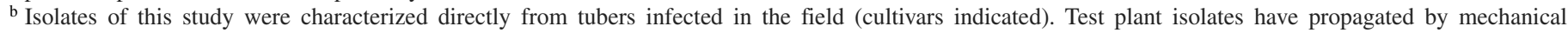
inoculation for a long time. Isolates from soil have been obtained using bait plants. Tuber nn = potato cultivar not known . 
spraing-expressing tubers were found to be PMTV-positive in this study, data indicated that the incidences of PMTV-infected tubers were 55 and $60 \%$ in Kardal, 33 and 39\% in Saturna, and 62 and 68\% in Nicola in 2006 and 2007, respectively. Consequently, the portions of symptomless tubers among PMTV-infected tubers were 100 and $90 \%$ in Kardal, 88 and $44 \%$ in Saturna, but only 2 and 12\% in Nicola in 2006 and 2007, respectively. Statistical analysis indicated that the incidences of PMTV-infected tubers, spraing-expressing tubers, and PMTV-infected symptomless tubers were different between the three cultivars and the two years (Table 3).

Bintje and Van Gogh were grown in the same experiment with other cultivars in 2006. The incidence of spraing-expressing tubers was 3 and $7 \%$ in the inspected lots of 483 and 511 tubers of Bintje and Van Gogh, respectively, and found to differ significantly between the cultivars (Table 3). Long-term experiments carried out with Bintje and Van Gogh in the same PMTV-infested fields during 8 years also show that spraing symptoms are less common in Bintje (incidence $8 \%$ on average) than Van Gogh (25\%) (unpublished data). PMTV was tested in 54 symptomless tubers of both cultivars by IC-RT-PCR in 2006 and found to be more common in the symptomless tubers of Bintje (52\%) than Van Gogh (12\%) (Fig. 4; Table 3). Hence, the latent infections with PMTV comprised $95 \%$ in Bintje and $63 \%$ in Van Gogh.

Symptomless infection with PMTV in potato minitubers. Five lots of 100 minitubers (cv. Saturna) were produced in a screenhouse in Latvia. No symptoms were observed but, depending on the lot, 3 to $13 \%$ of the minitubers were ELISA-positive $\left(\mathrm{A}_{405}=0.72\right.$ to 3.30; healthy tubers, $\mathrm{A}_{405}=0.01$ to 0.03$)$. Fourteen ELISA-positive tubers were tested also in Finland and found to be PMTV positive in DAS-ELISA and IC-RT-PCR. These minitubers had been grown from in vitro plantlets of cv. Saturna. Therefore, the stock of in vitro plants was also tested for PMTV by DAS-

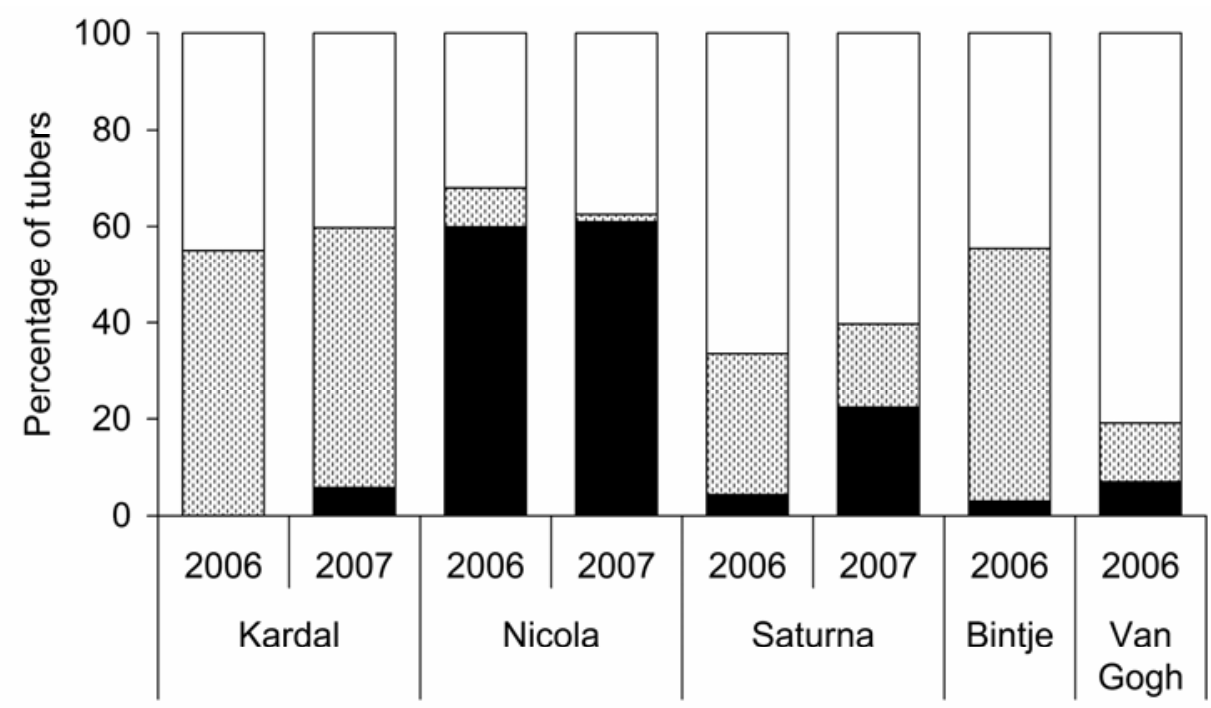

- Symptomatic 圆 Symptomless PMTV positive $\square$ Symptomless PMTV negative

Fig. 4. Percentage of Potato mop-top virus (PMTV)-infected tubers in the yields of different potato cultivars grown in the same PMTV-infested field. Among the PMTV-infected tubers, the proportions of tubers expressing spraing symptoms and symptomless tubers are indicated. For numbers of tubers inspected, see Results.

TABLE 3. Odds ratio estimates, $P$ values, and Wald confidence limits at 95\% for comparison of frequencies of symptomatic Potato mop-top virus (PMTV)-positive and symptomless PMTV-positive tubers and the incidence of PMTV-infected tubers between cultivars and years

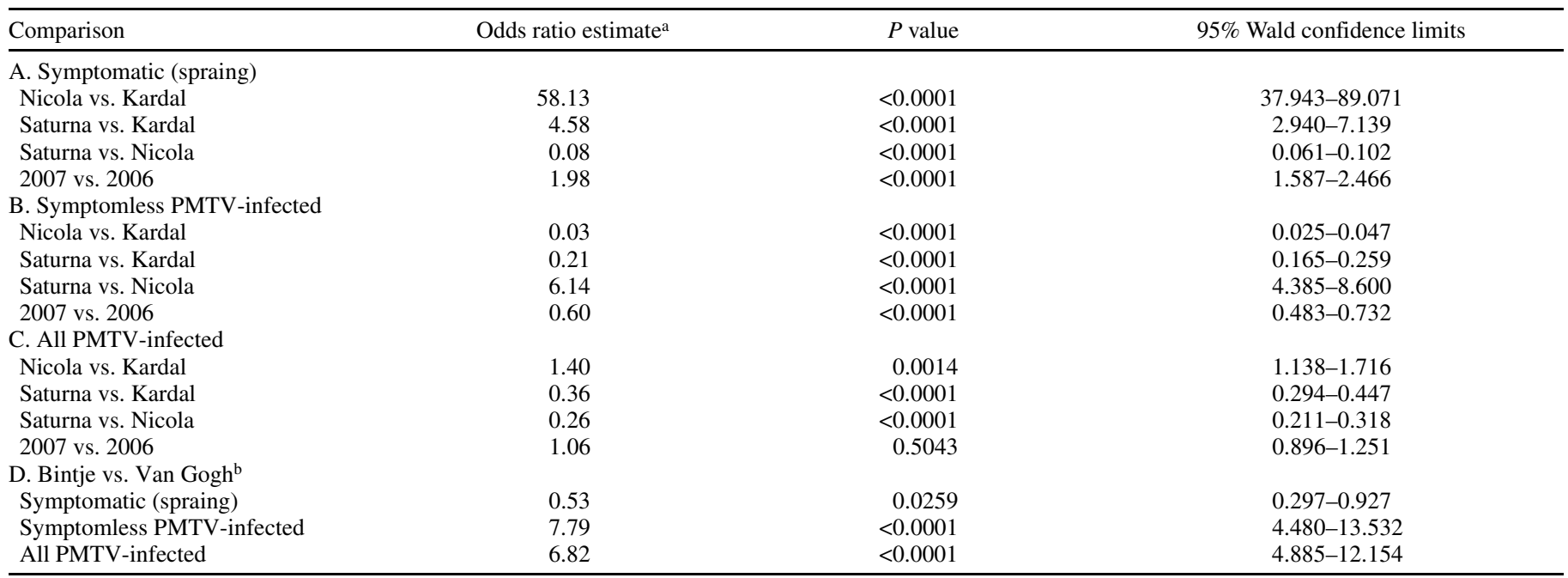

a Odds ratio: 1 is equivalent to no difference in the comparison; values $>1$ indicate increased probability in the first term; values $<1$ indicate increased probability in the second term. If unity $(=1)$ is not within the confidence interval, the comparison shows a significant difference. $\mathrm{CI}=$ confidence interval for odds ratio (Wald test).

${ }^{\mathrm{b}}$ Cvs. Bintje and Van Gogh were analyzed separately because they were tested only in 2006. 
ELISA. Results were negative (data not shown). The source of infection of the minitubers was not resolved and requires further study.

Detection of PMTV in potato sprouts. Because samples for ELISA and IC-RT-PCR are laborious to prepare from tubers, it was tested whether detection of PMTV would be feasible from sprouts. The sprouts $(>20 \mathrm{~mm})$ (Fig. 1) that developed after breakdown of dormancy in darkness in cool storage conditions contained detectable concentrations of PMTV, as tested by DASELISA. This is exemplified in Figure 5 with sprouts from tubers of Velox and Timo that generated the highest and lowest $\mathrm{A}_{405}$ values, respectively, among five cultivars tested (data not shown). Among the 25 sprouts tested from five tubers, 22 sprouts of Velox (Fig. 5A) and 24 sprouts of Timo (Fig. 5B) were deemed to be PMTV positive. Similar results were obtained in the experiments repeated twice (data not shown).

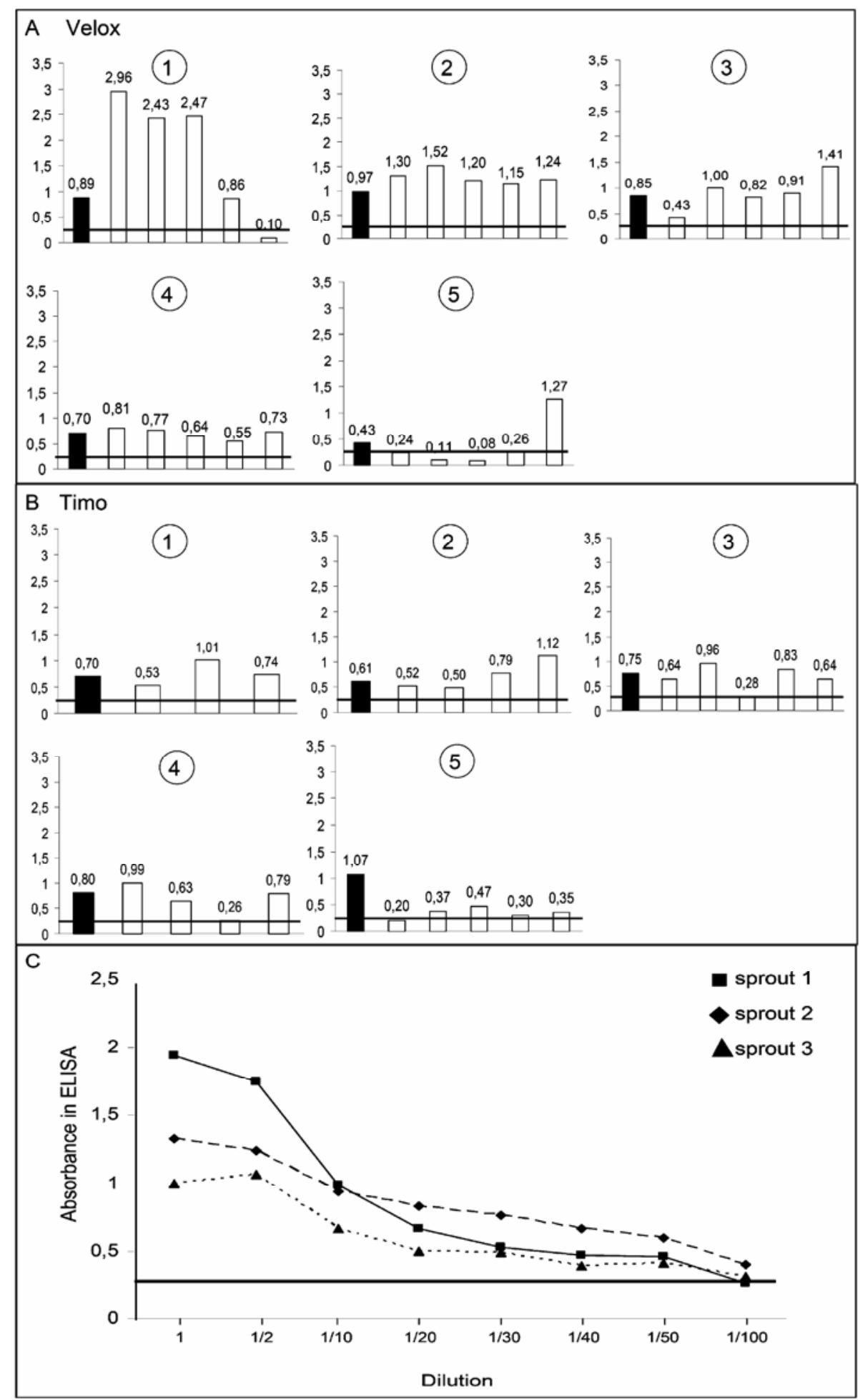

Fig. 5. A and B, Titers of Potato mop-top virus (PMTV) coat protein antigen in potato sprouts grown in dark (white bars) and tuber tissue (black bars) as detected by double-antibody sandwich enzyme-linked immunosorbent assay (ELISA) and indicated by absorbance values at $405 \mathrm{~nm}\left(\mathrm{~A}_{405}\right)$. Each of the five sprouts from five tubers (numbered 1-5) of cvs. Velox and Timo were tested separately. C, $\mathrm{A}_{405}$ values for the diluted sap of three sprouts. The sap of the PMTV-infected sprout was diluted (by the factors indicated) with the sap of healthy sprouts. The black horizontal line indicates the threshold value for samples to be considered viruspositive ( $3 \times$ the value of virus-free sprouts and tubers). 
It would be necessary to pool sprouts from many tubers if a large number of tubers (e.g., a representative sample from a seed potato lot) was to be tested. However, pooling of infected and healthy sprouts would increase the risk for false-negative results. Therefore, several experiments were done to estimate the lowest proportion of infected sprouts among virus-free sprouts detectable by DAS-ELISA, of which Figure 5C shows a representative result using three infected sprouts of Velox, each tested separately. The sap of the infected sprout was diluted ( $\mathrm{vol} / \mathrm{vol})$ with sap extracted from healthy sprouts. Results of three experiments suggested that
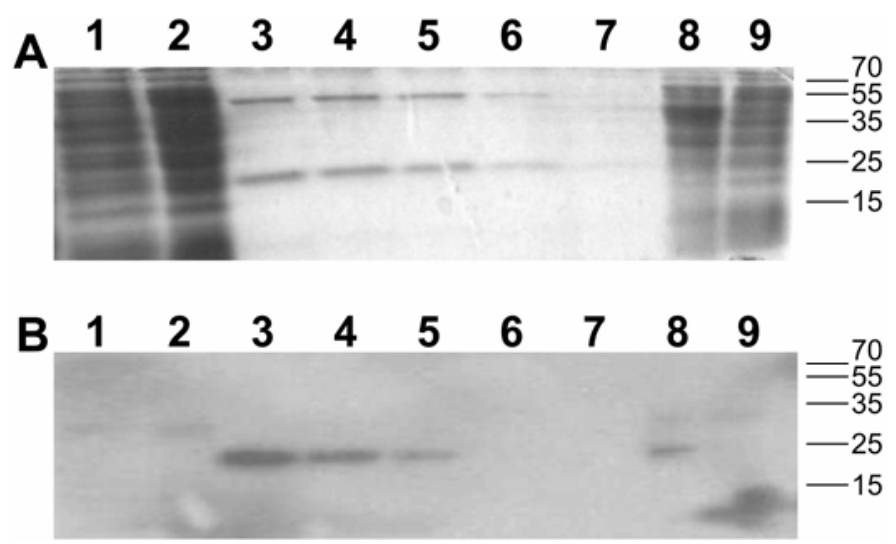

Fig. 6. Analysis of the 6xHis-tagged recombinant coat protein (CP) of Potato mop-top virus (PMTV) by sodium dodecyl sulfate polyacrylamide gel electrophoresis (above) and detection by western blot analysis (below). A, In the gel dyed with PageBlue protein staining solution, lanes 3 to 7 contain known amounts $(800,600,400,200$, and $100 \mathrm{ng}$, respectively) of bovine serum albumin (upper band) loaded for verification of the similar amounts of purified 6xHis-tagged CP (lower band) in the samples. B, The 6xHis-tagged $\mathrm{CP}$ is also detected with the anti-His tag monoclonal antibody in the western blot and used to estimate the concentration of $\mathrm{CP}$ in $10 \mu \mathrm{l}$ of the fivefoldconcentrated supernatant of a bacterial lysate analyzed in lane 8 . The signal strength corresponds to lane 5 in $\mathbf{A}$, indicating that the unconcentrated bacterial lysate contains $\mathrm{CP}$ at $8 \mathrm{ng} / \mu \mathrm{l}$. Lanes 1 and 2, noninduced and induced Escherichia coli M15 cells, respectively, lacking the protein expression plasmid; and lane 9, noninduced M15 cells containing the protein expression plasmid (negative controls to the induced cells, lane 8). The positions of protein size markers (PageRuler Plus Prestained Protein Ladder, Fermentas) are indicated to the right. a single infected sprout could be detected among 50 to 100 noninfected sprouts.

Detection threshold for PMTV CP antigen in tubers and sprouts using DAS-ELISA. The CP of PMTV was expressed in E. coli and known amounts of the recombinant 6xHis-tagged $\mathrm{CP}$ used for comparison to estimate the amounts of PMTV CP antigen in sprouts and tubers by DAS-ELISA. Concentrations of purified 6xHis-tagged $\mathrm{CP}$ were verified by comparison with known amounts of BSA in SDS-PAGE (Fig. 6A). The concentration of 6xHis-tagged $\mathrm{CP}$ in the supernatant of a bacterial lysate could be estimated by Western blot analysis using anti-His tag antibodies for detection and known amounts of purified 6xHistagged $\mathrm{CP}$ for comparison (Fig. 6B).

The recombinant PMTV CP remained in a native form and was detectable with the PMTV CP-specific MAb by DAS-ELISA in the supernatant of bacterial lysates. However, the purified denatured 6xHis-tagged $\mathrm{CP}$ was not detected with this MAb by DAS-ELISA. Attempts to purify the 6xHis-tagged CP under native conditions did not improve the situation. The 6xHis-tagged $\mathrm{CP}$ was also not detected in the bacterial lysates by western blot analysis using the PMTV CP-specific MAb (data not shown) in contrast to detection using the anti-His tag MAb (Fig. 6B). Furthermore, the wild-type PMTV CP could not be detected with the MAb in samples from PMTV-infected potato tubers or from leaves of PMTV-infected $N$. benthamiana plants using western blot analysis (data not shown). These data indicated that the epitope recognized by the anti-PMTV CP MAb is conformational and lost under denaturing conditions such as those of SDS-PAGE. Therefore, dilutions of the supernatants of bacterial lysates containing known amounts of recombinant PMTV CP (determined as explained above and in Figure 6) were used to estimate the amounts of PMTV CP antigens in sprout and tuber samples by DAS-ELISA.

When the same amount of recombinant PMTV CP was included in the ELISA samples prepared from healthy tubers and sprouts, ELISA absorbance values generated in sprout samples were approximately threefold higher than in tuber samples (Fig. 7). These results indicated that the detection threshold can be exceeded with a lower PMTV concentration in sprouts than tubers because tuber samples exhibit an inhibitory effect on ELISA. In practice, the samples from sprouts of a tuber generated higher, similar, or lower $\mathrm{A}_{405}$ values than the tuber but the mean ab-

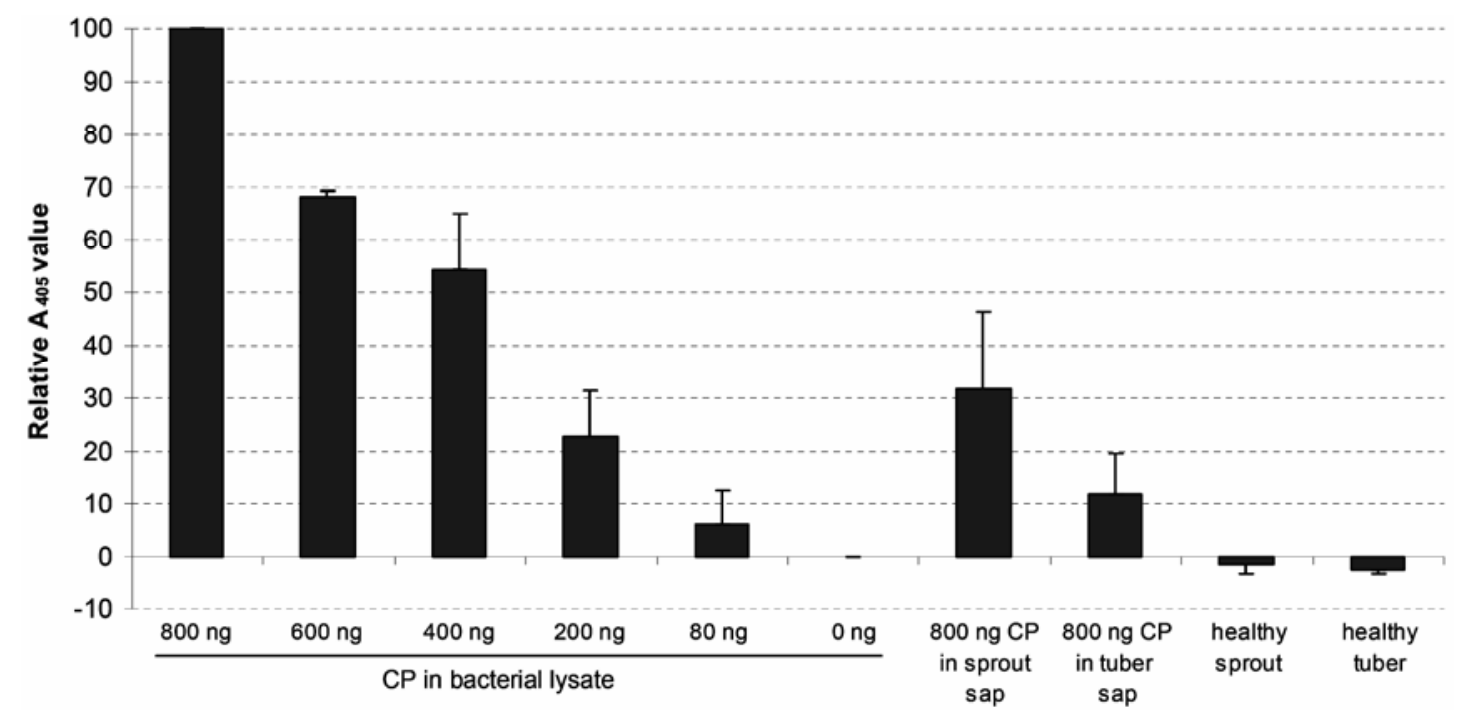

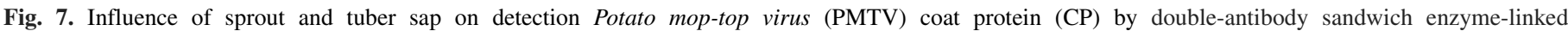

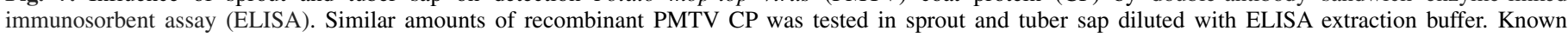

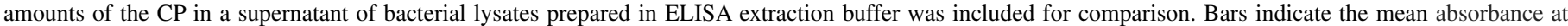

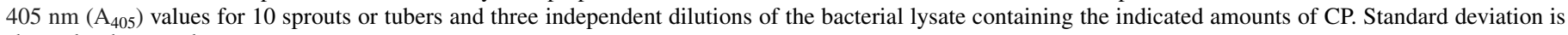
shown by the error bar. 
sorbance of all sprouts of a tuber was similar to that of the tuber (Fig. 5). Although this result suggested that many sprouts have a lower concentration of PMTV than the tuber, detection of PMTV in sprouts and tubers is expected to provide similar results in virus indexing. Therefore, indexing of large numbers of tubers can be facilitated using sprouts, which are more feasible for sample preparation.

Testing the same amount of recombinant PMTV CP in tuber and sprout sap diluted with ELISA extraction buffer or in the supernatant of bacterial lysate prepared in ELISA extraction buffer showed that absorbance values generated by sprout and tuber samples were $\approx 3$ - and 10 -fold lower than those of the supernatant, respectively (Fig. 7). When these differences were taken into consideration, it was estimated that PMTV CP concentrations higher than $0.5 \mu \mathrm{g} / \mathrm{g}$ of tissue were detectable by DAS-ELISA and the concentrations of PMTV CP antigen reached $57 \mu \mathrm{g} / \mathrm{g}$ of tissue in tubers (data not shown).

Indexing PMTV by mechanical inoculation to $N$. benthamiana. Mechanical inoculation of PMTV from sprouts to the indicator host $N$. benthamiana was tested preliminarily. Only 2 plants of the 25 plants of $N$. benthamiana inoculated with sap from five sprouts were systemically infected. Whether indexing tubers for PMTV by mechanical inoculation of the virus from sprouts is feasible and reliable requires further study. Using cooler plant growth conditions $\left(<16^{\circ} \mathrm{C}\right)$ might improve infection efficiency but such conditions were not available for the present study. However, the experiments showed that isolation of PMTV from sprouts to test plants is possible by mechanical inoculation.

Variability of the CP sequences. Because only some but not all PMTV-infected tubers displayed symptoms, we set out to study whether a particular strain or variant of PMTV was associated with symptoms. First, PMTV isolates from 18 spraingexpressing tubers and 5 symptomless minitubers were characterized for the CP- and RT-encoding sequences (RNA2) (Fig. 1; Table 2) by amplifying them as two separate clones that overlapped for 386 nt (Table 1; Fig. 3). The overlapping parts of the two sequences were identical in all samples studied, except one (see below). The CP gene sequences (AUG $+528 \mathrm{nt}$ ) of the 23 PMTV isolates characterized in this study were aligned with the previously determined CP nucleotide sequences of isolate PMTVT from Scotland (17), isolates 54-15 and 54-19 from Denmark (31), isolate Korneta from Czech Republic (5), and isolate PMTV$\mathrm{Sw}$ from Sweden (42). The first $21 \mathrm{nt}$ of the CP gene were excluded from analysis because they were absent from three of the five sequences in the database. These $21 \mathrm{nt}$ did not vary among the rest of the CP gene sequences.

The 28 PMTV CP gene sequences compared showed little variability and were 98 to $100 \%$ identical. Also, the deduced CP amino acid sequences were nearly identical (97 to 100\%). There were amino acid differences only at seven positions. Isolates PMTV-T, 1605, 2505, 1006, 50, and 75 had a Ser residue at position 11 instead of Ala found in other isolates. PMTV-T contained a Lys and a Gly residue at positions 2 and 57, respectively, instead of Arg found at both positions in other isolates. Isolate 5415 contained Ile and Cys at positions 66 and 114, respectively, whereas other isolates contained Leu and Gly at these positions. Isolate 54-19 had Gly instead of Arg at position 36. The Latvian isolate 29 had Cys at position 60, whereas all other isolates had Arg at this position.

Variability of the RT domain sequences. The RT domain sequences of 23 isolates determined in this study and the previously determined sequences of PMTV isolates 54-15, Korneta, and PMTV-Sw (Table 2) were of the same length (1,946 nt) and 97 to $100 \%$ identical. The Scottish isolate PMTV-T had a 468-nt deletion in the middle of the RT sequence, as previously noted (34). The 3'-proximal $165 \mathrm{nt}$ were identical in the Scottish isolates PMTV-T and PMTV-S (34) but these two isolates were highly divergent from all other isolates. Therefore, the Scottish isolates were excluded from further comparison of the RT domain sequences.

The remaining 25 RT sequences were 98 to $100 \%$ identical and contained a total of 24 variable amino acid positions. Isolate PMTV-Sw contained three unique amino acid residues-Val403, Pro463, and Ser499-instead of the Ala, Leu, and Phe residues, respectively, in other isolates. Only PMTV-Sw and isolate 705 contained Arg at position 431, whereas other isolates had a Gly at this position. Isolates $1605,1006,50$, and 75 contained the following amino acid substitutions compared with other isolates: Asn169Ser, Val320Ala, Ala448Val, Ala471Val, and Ile513Leu, respectively. Other amino acid substitutions included Pro76His in isolates PMTV-T, PMTV-S, 1605, 2505, and 75 and Arg209Ser in isolates 1006, 50, and 75 .

Phylogenetic analysis of CP and RT sequences. Analysis of the $\mathrm{CP}$ and RT nucleotide sequences by the neighbor-joining (Fig. 8)

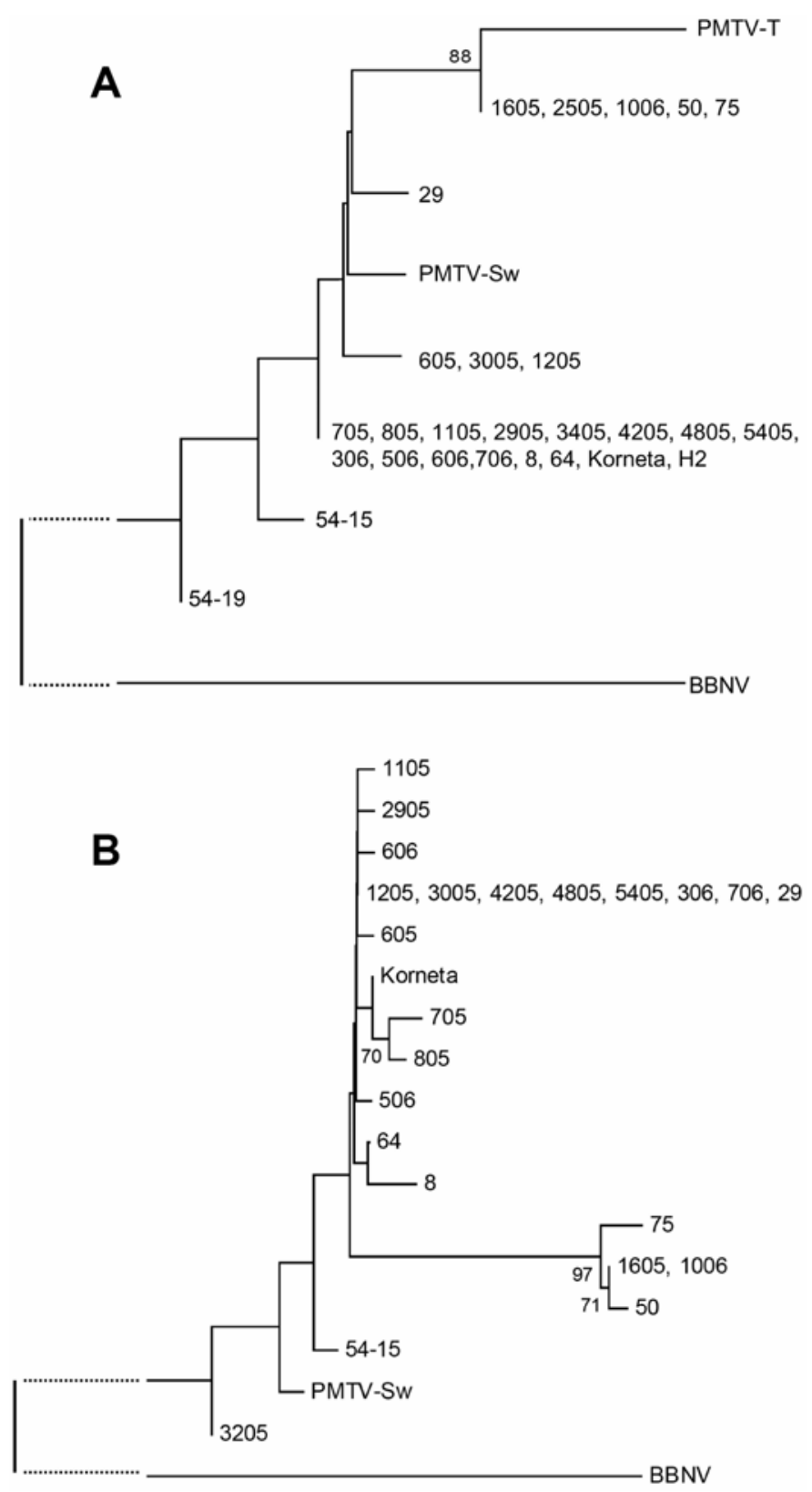

Fig. 8. Phylogenetic analysis by the neighbor-joining method of A, Potato mop-top virus (PMTV) coat protein gene sequences and $\mathbf{B}$, read-through domain sequences (RNA2). The corresponding sequences of Broad bean necrosis virus (BBNV, genus Pomovirus) (database accession no. NC_004424) (23) were used as an outgroup. Bootstrap values higher than 70 of 100 replications are shown. 
and maximum parsimony methods (data not shown) resulted in similar grouping of isolates to two clusters, which was more obvious with analysis of the RT sequences (Fig. 8B). Isolates 1605 and 1006 from Finland and 50 and 75 from Latvia formed a cluster different from other isolates (Fig. 8B) and were designated as group RNA2-I. The other isolates were designated as group RNA2-II. The two groups differed at $21 \mathrm{nt}$ positions within the RT domain. The RNA2 sequences available from PMTV-S and PMTV-T indicated that they belong to RNA2-I.

Variability of the $8 \mathrm{~K}$ gene and protein. PMTV isolates in tubers expressing spraing symptoms and in the five symptomless minitubers were also characterized for the 3 '-proximal part of the RNA3, including the $8 \mathrm{~K}$ gene (207 nt, 68 amino acids + stop codon) and the $3^{\prime}$ UTR (266 nt), which were amplified as a single RT-PCR product. The nucleotide sequences (473 nt) of 22 isolates determined in this study were compared with the corresponding sequences of five isolates available from the database (PMTV-Sw, PMTV-T, 54-10, 54-15, and Korneta) and found to be 96 to $100 \%$ identical. The 3'UTR was identical in most isolates and contained substitutions only at two positions, except PMTV-T that contained substitutions at $5 \mathrm{nt}$ positions. In contrast, the $8 \mathrm{~K}$ gene was highly variable. The $8 \mathrm{~K}$ amino acid sequences of isolates PMTV-Sw (Sweden), PMTV-T (Scotland), 50, 64, 75 (Latvia), and 1006 and 4205 (Finland) were identical (designated to group A) and differed from the remaining nearly identical sequences of isolates from Denmark, Finland, Latvia, and Czech Republic (group B) at eight amino acid positions (Fig. 9). Within group B, the variants observed included isolate 3205 (Finland) that contained a Val residue similar to group $\mathrm{A}$ at position 33, and isolate PMTV-D from Denmark (24) (no nucleotide sequence available) and isolate 8 from Latvia that each contained a unique amino acid residue (Ala-31 and Val-41, respectively) not found in other isolates. Placement of the $8 \mathrm{~K}$ sequences to groups $\mathrm{A}$ and $\mathrm{B}$ was supported also by phylogenetic analyses of the nucleotide and amino acid sequences with the neighbor-joining and maximum parsimony methods (data not shown).
Restrictotype analysis for detection of strains and mixed infections. The CP gene sequence characterized from tuber no. 2505 belonged to RNA2-II (Fig. 8), whereas the independently amplified region of RT belonged to RNA2-I (sequence 2505b). Examination of the overlapping part (region 308-694 in the RT; Fig. 3) revealed 3 nt differences between the two sequences (data not shown), which were those distinguishing RNA2-I and RNA2II in this part of the sequence. Therefore, it was likely that the amplification products were not obtained from the same RNA2 template but the tuber was infected with both types of RNA2. Results from this tuber and the occurrence of two types of RNA2 and RNA3 in PMTV prompted us to study possible mixed infections in tubers, which was done by analysis of restriction patterns (restrictotypes) of the digested PCR products. Examples of results are shown in Figure 10. This approach was considered to be efficient for detecting the types of PMTV strains in tubers.

Co-occurrence of RNA2-II with RNA3-B was found to be most common ( 8 of the 14 tubers tested) (Table 4$)$. This combination was detected in tubers expressing spraing symptoms and also in symptomless tubers. One tuber (Ea) contained the combination of RNA2-I and RNA3-B (Fig. 10) and expressed spraing symptoms.

More complex mixtures of PMTV RNAs were also detected. Both types of RNA2 (I and II) were detected in combination with RNA3-A (tuber Cb) (Fig. 10) or RNA3-B (tubers Cecile1 and Seresta) (Table 4). All these tubers expressed spraing symptoms. The symptomless tuber C2 contained both types of RNA3 (Fig. 10) but RNA2 was not tested. One tuber (P2) contained all types of RNAs (RNA2 types I and II and RNA3 types A and B) and expressed the spraing disease. Hence, there was no specific type of RNA2 or RNA3 or their combination that was associated with symptoms or lack of them.

PCR products from tubers $\mathrm{Ea}, \mathrm{P} 2$, and $\mathrm{C} 2$ were cloned and sequenced. The 1,248- and 544-nt products from tuber Ea were identical to isolates 1006 (RNA2-I) and 5405 (RNA3-B), respectively (Figs. 8 and 9). The 544-nt products from tuber P2 and C2 both contained two different sequences which, in both tubers, were identical to isolates 4205 (RNA3-A) and 5405 (RNA3-B).
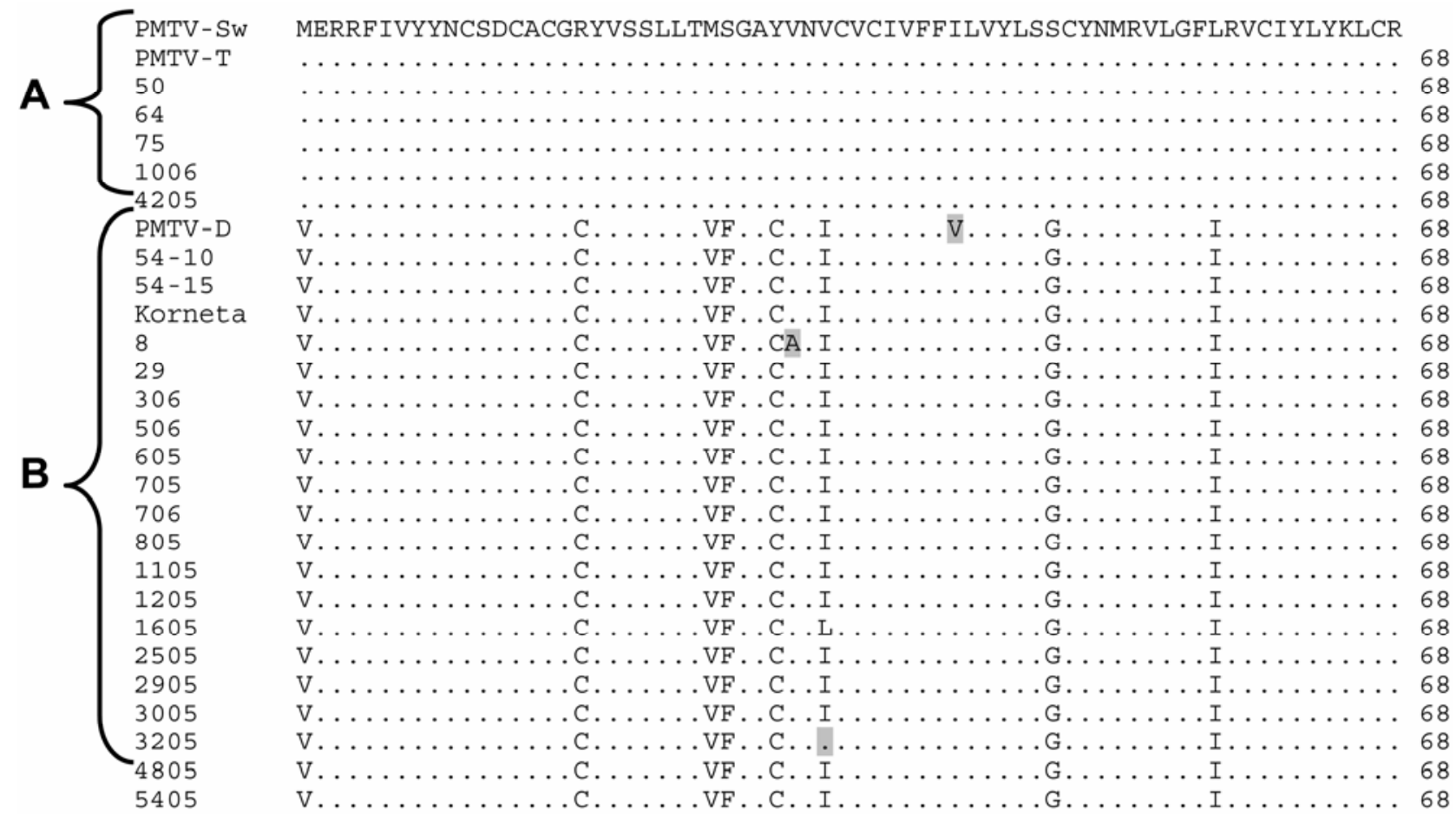

Fig. 9. Alignment of the deduced Potato mop-top virus (PMTV) 8K protein amino acid sequences compared with the amino acid sequence of PMTV-Sw. Only residues different from those of PMTV-Sw are shown. Identical amino acids are indicated by dots. The two distinguishable groups of sequences are indicated with A and B. Unique amino acid residues in group B are shaded. 


\section{DISCUSSION}

The results of this study indicate that PMTV consists of a heterogeneous RNA population in the field. Analysis of PMTV from 37 potato tubers naturally infected in the field in different parts of Finland revealed two distinguishable types of RNA2 and RNA3. The combination of RNA2-II and RNA3-B was more common than any other combination and comprises the typical genomic composition of PMTV strains infecting potato in the field in Finland. Only a few PMTV sequences are available from other countries in the sequence databases but, according to the results of Nielsen and Nicolaisen (29), two major restrictotypes of Danish PMTV strains could be distinguished based on the RT domain sequences, similar to this study. Judged based on the limited information on PMTV sequences available from other countries, it seems that RNA2-II and RNA3-B are the most common in PMTV also in other areas. In another tripartite RNA plant virus, Cucumber mosaic virus (CMV), the reassortment of genomic RNAs is not favored in natural populations (9). The reassortants that do occur do not represent random association of the three genomic RNAs. Although genomic reassortment may act as a source of variability for viral evolution (7) and a tool against deleterious mutation accumulation in virus populations (27), reassortment of genomic RNAs between two genetic groups of the same virus can also result in biological disadvantages for the virus. For example, these disadvantages can be associated with diminishing specification in protein-protein or protein-RNA interactions (9). Similar reasons may also explain why one of the four possible combinations of RNA2 and RNA3 of PMTV is more common than the others in the field.

Genetic diversity of PMTV was largely confined to existence of the two alternative types of RNA2 and RNA3, whereas each of these types of the RNA showed little variability. Furthermore, the lengths of the characterized regions did not vary among the isolates of this study. Careful analysis of sequences revealed no indication of artificial recombinants resulting from PCR artifacts, which could be a risk in samples consisting of mixtures of nearly identical RNA sequences $(18,19)$. Although RNA2 was almost entirely characterized, only the 3 '-terminal $544 \mathrm{nt}$ were analyzed from RNA3 and variability of other parts of this RNA is un-

TABLE 4. Detection of the types of RNA2 and RNA3 in potato tubers by restrictotype analysis

\begin{tabular}{lllll}
\hline & & & \multicolumn{2}{c}{$\begin{array}{c}\text { Genomic region and } \\
\text { restrictotype }^{\mathrm{c}}\end{array}$} \\
\cline { 4 - 5 } Sample $^{\mathrm{a}}$ & & & & Cultivar \\
\cline { 4 - 5 } & Spraing symptoms & RNA2 & RNA3 \\
\hline A7 & Nicola & No & II & B \\
A12 & Nicola & No & II & B \\
Aa & Tuber nn & No & II & B \\
Bb & Tuber nn & Yes & II & B \\
C2* & Tuber nn & Yes & II & B \\
Cb & Tuber nn & Yes & nd & A+B \\
Cecile1 & Cecile & Yes & I+II & A \\
Cecile2 & Cecile & Yes & II & B \\
D10 & Tuber nn & No & II & B \\
Ea* & Tuber nn & Yes & I & B \\
P1 & Velox & Yes & II & B \\
P2* & Nicola & Yes & I+II & A+B \\
Seresta & Seresta & Yes & I+II & B \\
\hline
\end{tabular}

${ }^{a}$ Amplification products from samples marked with an asterisk were sequenced to verify the result of the restrictotype analysis.

b Tuber $\mathrm{nn}=$ cultivar not known

${ }^{c}$ nd $=$ not determined.
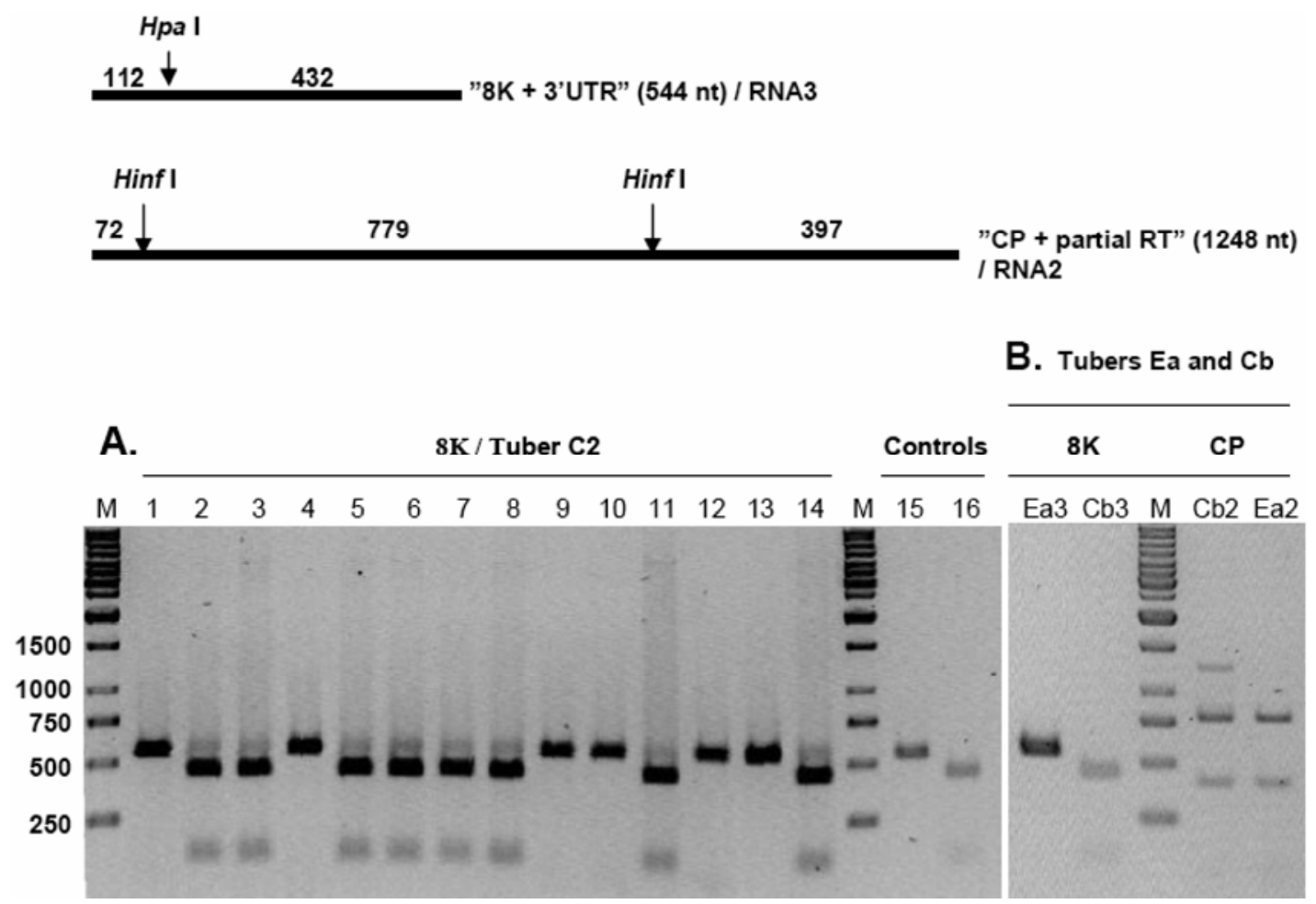

Fig. 10. Restrictotype analysis revealing mixed infections with Potato mop-top virus (PMTV) strains and strains with different combinations of the two types of RNA2 and RNA3 in potato tubers. The expected restriction fragments obtained from the amplified fragments of RNA3 and RNA2 belonging to groups A and I, respectively, are indicated on the top. A, Mixed infection with isolates carrying group A and B type of RNA3 in tuber sample C2. Lanes 1-14 contain polymerase chain reaction (PCR) products that were obtained from a single tuber, cloned in Escherichia coli, reamplified by PCR from single colonies of the bacteria after cloning, and subjected to digestion with HpaI. Clones 1, 4, 9, 10, 12, and 13 were not digested and belong to group B. Other clones were digested and belong to group A. Results were verified by sequencing the PCR products. Lanes 15 and 16, controls (sequenced clones) of groups B and A, respectively. B, Different combinations of RNA2 and RNA3 in tuber samples. In tuber Ea, RNA3 (8K) belongs to restrictotype B, whereas RNA2 (CP) belongs to restrictotype I. In tuber $\mathrm{Cb}$, RNA3 belongs to the restrictotype A. However, both restrictotypes of RNA2 (I and II) are detected. M, molecular weight marker (Gene Ruler 1-kb DNA Ladder, Fermentas), of which the positions of markers of 1,500, 1,000, 750, 500, and $250 \mathrm{bp}$ are indicated; RT = readthrough; $3^{\prime} \mathrm{UTR}=3^{\prime}$ untranslated region. 
known. However, the PMTV isolates of the present study can be considered comprehensively characterized compared with the isolates reported in most of the previous studies. The results indicated limited genetic variability of PMTV isolates, as found in the previous studies in which the CP sequences of three Scottish and eight Peruvian isolates of PMTV were analyzed (25). Similarly, the CP sequences of six North American isolates of PMTV were $>97 \%$ identical to sequences of the few European PMTV isolates available at that time (51). Unfortunately, the sequence data of these two studies are not available in databases except for one isolate from Canada (51) whose CP sequence is identical to many isolates carrying RNA2-II. It has been hypothesized that the RT or the CP-RT protein may be involved in transmission of PMTV by $S$. subterranea (34). Therefore, the dependence on vector transmissibility may limit the variability and also require the existence of these proteins in PMTV isolates in the field. All tested tubers with spraing symptoms and also many symptomless tubers gave positive results when tested with a MAb specific to the PMTV CP antigen. These results are different from those observed with the nematode-transmitted TRV that is found to infect potato tubers without RNA2 which contains the CP gene and the genes required for vector transmission $(12,13,33,50)$. Neither PMTV nor TRV is dependent on RNA2 for systemic infection of plants $(11,26,33,42)$.

The relatively small $8 \mathrm{~K}$ gene contained substitutions in 13 positions, of which 8 resulted in amino acid substitutions. This strong positive selection suggests that the $8 \mathrm{~K}$ protein plays an important role in the infection cycle or transmission of PMTV. One of the variable positions was in the translation start codon AUG (Met) (RNA3-A) which, in some isolates, was replaced by the putatively less efficient GUG (Val) (RNA3-B). Similar differences have been previously noted in Danish, Scottish, and Swedish isolates (24). The $8 \mathrm{~K}$ protein of PMTV is a virulence factor that induces necrotic symptoms in Nicotiana spp. when expressed from heterologous viruses (24). Therefore, it was of interest to study whether RNA3-A or RNA3-B was associated with the necrotic symptoms (spraing) in tubers. The restrictotype analysis and sequencing of the $8 \mathrm{~K}$ gene did not, however, support preferential association of any particular type of RNA3 with spraing symptoms. Both types were detected in symptom-expressing and symptomless tubers. Similar results were obtained with detection of the two types of RNA2 in tubers. Furthermore, this first and, thus far, only detected occurrence of PMTV in Latvia revealed no difference in the genetic composition of the types of RNA2 and RNA3 in the minitubers infected in the screenhouse in Latvia and in spraing-expressing tubers grown in the field in Finland or reported from elsewhere. It seems that all PMTV strains are capable of inducing spraing symptoms. Other possible biological differences of PMTV isolates associated with the different RNA2 and RNA3 variants remain as a topic for future studies.

The lack of symptoms in a large number of minitubers of Saturna infected with PMTV in a screenhouse in Latvia and the large proportion of symptomless, PMTV-infected tubers among the spraing-expressing tubers in most potato cultivars grown in the field underline the role of the physiological stage of tubers and environmental conditions in spraing development $(21,39)$. The data of this study also show that potato cultivars differ in their propensity to develop spraing symptoms following infection. Almost all PMTV-infected tubers of Nicola developed spraing symptoms, whereas almost all infected tubers in Kardal remained symptomless in the experiments carried out in the same field in 2 years. Bintje, Saturna, and Van Gogh also had a large proportion of PMTV-infected tubers that were symptomless. The results from experiments carried out over 8 years in the field in Finland show that the differences between cultivars are rather consistent over time (unpublished data). However, as found in this study with Kardal, Nicola, and Saturna, the incidence of infection and the proportion of spraing-expressing tubers among infected tubers differs between years. The differences observed in this study were rather modest, probably because the weather conditions were quite similar in the 2 years. The only clear difference was that there were 23 rainy days in July 2007 compared with 5 days in 2006. Hence, soil moisture was higher from tuber initiation to harvest in 2007, which may have increased infection pressure with S. subterranea (15). Previous studies in Sweden (39), Denmark (28), and Finland (22) have reported differences in the incidence of spraing symptoms between cultivars but the incidence of symptomless, infected tubers has gained less attention. Evaluation of some potato breeding lines in field trials in Sweden in 2 years revealed that $50.2 \%$ of all PMTV-infected tubers detected in the experiment were symptomless and there were large differences in the incidence of symptomless PMTV-infected tubers among the breeding lines (40).

The common occurrence of symptomless infections, no evidence for a particular type of PMTV strain required for symptom induction, and no infections without RNA2 which could have been detected in the restrictotype analysis indicate that indexing tubers for PMTV with anti-CP antibodies or using CP gene specific primers in IC-RT-PCR is both necessary and reliable. These findings led us to think about methods that could facilitate indexing seed potato lots for PMTV. Otherwise, the use of symptomless, PMTV-infected seed tubers could possess a risk of contaminating new fields with the virus, provided that the vector was present. For example, although the in vitro plantlets of Saturna propagated for planting in the screenhouse in Latvia were virus free as tested by DAS-ELISA, the minitubers produced by the plants were PMTV infected and aimed to be planted to the field. They exhibited no symptoms and would not have been detected as PMTV-infected without indexing by DAS-ELISA. The source of PMTV in this material is still not known. The mixture of peat and soil used in the screenhouse or dust spread by wind from potato fields containing viruliferous sporangia of S. subterranea were the suspected sources of contamination with PMTV. However, studies carried out since 2005 have found no evidence of PMTV in the potato fields in Latvia (unpublished data).

Using sprouts rather than tuber tissue for ELISA was considered to make sampling and sample preparation much less time consuming. This approach has not been used for testing PMTV, as far as we are aware. It seemed to work well due to its easiness and similarity to sample preparation from leaves which is routinely used for testing other viruses. Sprouts, on average, gave absorbance values similar to those of tubers, which suggested that testing sprouts is at least as sensitive as testing tubers. In addition, sprout sap exhibited less interference with ELISA. The examined possibility of pooling 50 sprouts to one sample facilitates largescale indexing of tuber lots. Using IC-RT-PCR might provide even higher detection sensitivity.

\section{ACKNOWLEDGMENTS}

S. Latvala-Kilby and J. M. Aura contributed equally to this study, which was carried out under the MOP-TOP research program supported by the Nordic Joint Committee for Agricultural Research (NKJ, project no. 122). Financial support from NKJ and the Ministry of Agriculture and Forestry, Finland (grant 1386/39/2005), is gratefully acknowledged. We thank H. Ojanen for preparation of Figure 1, S. Tuominen for technical assistance, and participants of the annual meetings for fruitful discussions and helpful suggestions.

\section{LITERATURE CITED}

1. Allison, P. D. 1999. Logistic Regression Using the SAS System: Theory and Application. SAS Institute Inc., Cary, NC, USA.

2. Balhoff, J. P., and Wray, G. A. 2005. Evolutionary analysis of the well characterized endo16 promoter reveals substantial variation within functional sites. Proc. Natl. Acad. Sci. USA 102:8591-8596. 
3. Björnstad, A. 1969. Spredning av potet-mop-topp-virus (PMTV) med settepotater. Jord Avling 2:2-4.

4. Calvert, E. L., and Harrison, B. D. 1966. Potato mop-top a soil-borne virus. Plant Pathol. 15:134-139.

5. Cerovska, N., Moravec, T., Rosecka, P., Filigarova, M., and Pecenkova, T. 2003. Nucleotide sequences of coat protein coding regions of six potato mop-top virus isolates. Acta Virol. 47:37-40.

6. Cerovska, N., Pecenkova, M., Foligarova, M., and Dedic, P. 2007. Sequence analysis of the Czech Potato mop-top virus (PMTV) isolate Korneta-Nemilkov. Folia Microbiol. 52:61-64.

7. Chao, L. 1992. Evolution of sex in RNA viruses. Trends Ecol. Evol. 7:147-151.

8. Chenna, R., Sugawara, H., Koike, T., Lopez, R., Gibson, T. J., Higgins, D. G., and Thompson, J. D. 2003. Multiple sequence alignment with the Clustal series of programs. Nucleic Acids Res. 31:3497-3500.

9. Fraile, A., Alonso-Prados, J. L., Aranda, M. A., Bernal, J. J., Malpica, J. M., and Garcia-Arenal, F. 1997. Genetic exchange by recombination or reassortement is infrequent in natural populations of a tripartite RNA plant virus. J. Virol. 71:934-940.

10. Harrison, B. D, and Jones, R. A. C. 1970. Host range and some properties of potato mop-top virus. Ann. Appl. Biol. 65:393-402.

11. Harrison, B. D., and Robinson, D. J. 1978. The Tobraviruses. Adv. Virus Res. 23:25-77.

12. Harrison, B. D., Robinson, D. J., Mowat, W. P., and Duncan, G. H. 1983. Comparison of nucleic acid hybridisation and other tests for detecting tobacco rattle virus in narcissus plants and potato tubers. Ann. Appl. Biol. 102:331-338

13. Hernandez, C., Mathis, A., Brown, D. J. F., and Bol, J. F. 1995. Sequence of RNA 2 of nematode-transmissible isolate of tobacco rattle virus. J. Gen. Virol. 76:2847-2851.

14. Imoto, M., Tochihara, H., Iwaki, M., and Nakamura, H. 1981. (Occurence of potato mop-top virus in Japan). Ann. Phytopathol. Soc. Jpn. 47:409.

15. Jones, R. A. C., and Harrison, B. D. 1969. Behaviour of potato mop-top virus in soil and evidence for its transmission by Spongospora subterranea (Wallr) Lagerh. Ann. Appl. Biol. 63:1-8.

16. Kallender, H., Buck, K. W., and Brunt, A. A. 1990. Association of 3 RNA molecules with Potato mop-top virus. Neth. J. Plant Pathol. 96:47-50.

17. Kashiwazaki, S., Scott, K. P., Reavy, B., and Harrison, B. D. 1995. Sequence analysis and gene content of potato mop-top virus RNA 3: Further evidence of heterogeneity in the genome organization of furoviruses. Virology 206:701-706.

18. Koenig, R., and Büttner, G. 2004. Strategies for the detection of potential Beet necrotic yellow vein virus genome recombinations which might arise as a result of growing A type coat protein gene-expressing sugarbeets in soil containing B type virus. Transgenic Res. 13:21-28.

19. Koenig, R., Büttner, G., and Loss, S. 2003. Experiences in the search for possibly occurring recombinations between $\mathrm{A}$ and $\mathrm{B}$ type beet necrotic yellow vein virus in transgenic and mixed infected sugarbeets. Pages 1-4 in: Proc. Fifth Symp. Int. Working Group on Plant Viruses with Fungal Vectors. C. M. Rush and U. Mertz, eds. American Society of Sugarbeet Technologists, Denver.

20. Kumar, S., Tamura, K., and Nei, M. 2004. MEGA3: Integrated software for molecular evolutionary genetics analysis and sequence alignment. Brief. Bioinform. 5:150-163.

21. Kurppa, A. 1989. The distribution and incidence of Potato mop-top virus in Finland as determined in 1987 and on the variation of disease symptoms in infected potatoes. Ann. Agric. Fenn. 28:285-295.

22. Kurppa, A. 1989. Reaction of potato cultivars to primary and secondary infection by potato mop-top Furovirus and strategies for virus detection. EPPO Bull. 19:593-598.

23. Lu, X., Yamamoto, S., Tanaka, M., Hibi, T., and Namba, S. 1998. The genome organization of the broad bean necrosis virus (BBNV). Arch. Virol. 143:1335-1348.

24. Lukhovitskaya, N. I., Yelina, N. E., Zamyatnin, A. A., Jr., Schepetilnikov, M. V., Solovyev, A. G., Sandgren, M., Morozov, S. Yu., Valkonen, J. P. T., and Savenkov, E. I. 2005. Expression, localization and effects on virulence of the cysteine-rich 8-kDa protein of Potato mop-top virus. J. Gen. Virol. 86:2879-2889.

25. Mayo, M. A., Torrance, L., Cowan, G., Jolly, C. A., Macintosh, S. M., Orrega, R., Barrera, C., and Salazar, L. F. 1996. Conservation of coat protein sequence among isolates of potato mop-top virus from Scotland and Peru. Arch. Virol. 141:1115-1121.

26. McGeachy, K. D., and Barker, H. 2000. Potato mop-top virus RNA can move long distance in the absence of coat protein: Evidence from resistant, transgenic plants. Mol. Plant-Microbe Interact. 13:125-128.

27. Müller, H. L. 1964. The relation of recombination to mutational advance. Mutat. Res. 1:2-9.
28. Nielsen, S. L., and Mølgaard, J. P. 1997. Incidence, appearance and development of potato mop-top Furovirus-induced spraing in potato cultivars and the influence on yield, distribution in Denmark and detection of the virus in tubers by ELISA. Potato Res. 40:101-110.

29. Nielsen, S. L., and Nicolaisen, M. 2003. Identification of two nucleotide sequence sub-groups within Potato mop-top virus. Arch. Virol. 148:381-388.

30. Novak, J. B., Rasocha, V., and Lanzova, J. 1983. (Demonstration of potato mop-top virus in Czechoslovak Sosialist Republik). Sbornik UVTIZ Ochrana Rostlin 19:161-167.

31. Pecenkova, T., Moravec, T., Filigarova, M., Rosecka, P., and Cerovska, N. 2004. Extended sequence analysis of three Danish Potato mop-top virus (PMTV) isolates. Virus Genes 29:249-255.

32. Peterson, B., and Harrell, F. E. 1990. Partial proportional odds models for ordinal response variables. Appl. Stat. 39:205-217.

33. Ploeg, A. T., Robinson, D. J., and Brown, D. J. F. 1993. RNA-2 of tobacco rattle virus encodes the determinants of transmissibility by trichodorid vector nematodes. J. Gen. Virol. 74:1463-1466.

34. Reavy, B., Arif, M., Cowan, G. H., and Torrance, L. 1998. Association of sequences in the coat protein/readthrough domain of potato mop-top virus with transmission by Spongospora subterranea. J. Gen. Virol. 79:23432347.

35. Rowhani, A., Biardi, L., Routh, G., Daubert, S. D., and Golino, D. A. 1998. Development of a sensitive colorimetric-PCR assay for detection of viruses in woody plants. Plant Dis. 82:880-884.

36. Ryden, K., Eriksson, B., and Insunza, V. 1986. Rostringar hos potatis ursakade av potatismopptoppvirus (PMTV). Växtskyddsnotiser 50:97102.

37. Saitou, N., and Nei, M. 1987. The neighbor-joining method: a new method for recontsructing phylogenetic trees. Mol. Biol. Evol. 4:406-425.

38. Salazar, L. F., and Jones, R. A. C. 1975. Some studies on the distribution and incidence of potato mop-top virus in Peru. Am. Potato J. 52:143-150.

39. Sandgren, M. 1995. Potato mop-top virus (PMTV): distribution in Sweden, development of symptoms during storage and cultivar trials in field and glasshouse. Potato Res. 38:387-397.

40. Sandgren, M., Plaisted, R. L., Watanabe, K. N., Olsson, S., and Valkonen, J. P. T. 2002. Evaluation of some North and South American potato breeding lines for resistance to Potato mop-top virus in Sweden. Am. J. Potato Res. 79:205-210.

41. Sandgren, M., Savenkov, E. I., and Valkonen, J. P. T. 2001. The readthrough region of Potato mop-top virus (PMTV) coat protein encoding RNA, the second largest RNA of PMTV genome, undergoes structural changes in naturally infected and experimentally inoculated plants. Arch. Virol. 146:467-477.

42. Savenkov, E. I., Germundsson, A., Zamyatnin, A. A., Jr., Sandgren, M., and Valkonen, J. P. T. 2003. Potato mop-top virus: The coat proteinencoding RNA and the gene for cysteine-rich protein are dispensable for systemic virus movement in Nicotiana benthamiana. J. Gen. Virol. 84:1001-1005

43. Savenkov, E. I., Sandgren, M., and Valkonen, J. P. T. 1999. Complete sequence of RNA 1 and the presence of tRNA-like structures in all RNAs of Potato mop-top virus, genus Pomovirus. J. Gen. Virol. 80:2779-2784.

44. Scott, K. P., Kashiwazaki, S., Reavy, B., and Harrison, B. D. 1994. The nucleotide-sequence of potato mop-top virus RNA2 - a novel type of genome organization for a Furovirus. J. Gen. Virol. 75:3561-3568.

45. Tenorio, J., Franco, Y., Chuquillanqui, C., Owens, R. A., and Salazar, L. F 2006. Reaction of potato varieties to Potato mop-top virus infection in the Andes. Am. J. Potato Res. 83:423-431.

46. Torrance, L., Cowan, G. H., Sokmen, M. A., and Reavy, B. 1999. A naturally occurring deleted form of RNA 2 of Potato mop-top virus. J. Gen. Virol. 80:2211-2215.

47. Torrance, L., and Mayo, M. 1997. Proposed re-classification of furoviruses. Arch. Virol. 142:435-439.

48. van Hoof, A. A., and Rozandaal, A. 1969. Het voorkomen van 'potato mop-top virus' in Netherhald. Neth. J. Plant Pathol. 75:275.

49. Vincze, T., Posfai, J., and Roberts, R. J. 2003. NEBcutter: a program to cleave DNA with restriction enzymes. Nucleic Acids Res. 31:3688-3691.

50. Weidemann, H.-L. 1995. Detection of tobacco rattle virus in potato tubers and roots by polymerase chain reaction (PCR). J. Phytopathol. 143:455458

51. Xu, H., DeHaan, T. L., and De Boer, S. H. 2004. Detection and confirmation of Potato mop-top virus in potatoes produced in the United States and Canada. Plant Dis. 88:363-367.

52. Zamyatnin, A. A., Solovyev, A. G., Savenkov, E. I., Germundsson, A., Sandgren, M., Valkonen, J. P. T., and Morozov, S. Y. 2004. Transient coexpression of individual genes encoded by the triple gene block (TGB) of Potato mop-top virus reveals requirements for TGBp1 trafficking. Mol. Plant-Microbe Interact. 17:921-930. 